\title{
Improving Water Sustainability through Modeling Optimum Sites for Riparian Forest Reforestation
}

\author{
Daniel Henrique Alves Torres, Dácio de Castro Vivas Neto, Danilo Vieira Mendes dos Santos and Carlos Alberto \\ Pereira Soares *(1)
}

Citation: Torres, D.H.A.; Vivas Neto, D.d.C.; Santos, D.V.M.d.; Soares, C.A.P. Improving Water Sustainability through Modeling Optimum Sites for Riparian Forest Reforestation. Water 2021, 13, 46. https://doi.org/10.3390/w13010046

Received: 29 November 2020 Accepted: 24 December 2020 Published: 29 December 2020

Publisher's Note: MDPI stays neutral with regard to jurisdictional clai$\mathrm{ms}$ in published maps and institutional affiliations.

Copyright: (C) 2020 by the authors. Licensee MDPI, Basel, Switzerland. This article is an open access article distributed under the terms and conditions of the Creative Commons Attribution (CC BY) license (https:// creativecommons.org/licenses/by/ $4.0 /)$.
Pós-Graduação em Engenharia Civil, Universidade Federal Fluminense, Niterói 24210-240, Brazil; danieltorres@id.uff.br (D.H.A.T.); daciovivas@id.uff.br (D.d.C.V.N.); danilomendes@id.uff.br (D.V.M.d.S.)

* Correspondence: capsoares@id.uff.br; Tel.: +55-21-2629-5410

\begin{abstract}
The margins of Brazilian rivers are considered Permanent Preservation Areas-APPs, due to the riparian forest's water resource preservation capacity. However, a significant portion of the Brazilian Atlantic Forest biome, in which the Jacaré River basin is located, has suffered increasing deforestation over the past decades. This research aimed to use a methodology integrating Geographic Information System (GIS), fuzzy logic, Analytic Hierarchy Process (AHP), and sensitivity analysis to model the selection of riparian protected area stretches that presents the best successful riparian forest reforestation using a real case, the Jacaré river basin, whose characteristics are often in Brazilian watersheds. To identify the main drivers that influence reforestation success, we carried out a broad and detailed bibliographic research. To establish the relative importance among the drivers, we conducted a survey with experts. The results showed that areas with moderate chances of reforestation prevail in the studied region. Due to the areas' distribution pattern, a significant portion of the best sites were grouped, forming regions that create environments that favor aquatic and riverside life development and ecological balance maintenance, thus bringing together fundamental characteristics to improve water resources sustainability. The best sites have dystrophic or eutrophic soil, with a slope of up to $15 \%$. Besides, they are mainly covered by grass and are close to forest fragments with low vulnerability.
\end{abstract}

Keywords: water sustainability; reforestation; riparian forest; geographical information system; analytical hierarchy process; fuzzy logic

\section{Introduction}

Studies aiming at water resources sustainability have increasingly aroused the researchers' interest. In Brazil, as in most developing countries, human actions, especially those related to land use and deforestation, associated with natural phenomena, have caused significant changes in the quality and quantity of these resources.

Brazil's National Water Resources Policy created the National Water Resources Management System, which has the preservation and recovery of water resources as one of its objectives. Brazilian legislation establishes that riverbanks are Permanent Preservation Areas-APPs, called "Faixa Marginal de Proteção" (FMP), with the environmental function of preserving water resources, the landscape, geological stability, biodiversity, gene flow of fauna and flora and protecting the soil.

The main objective of FMP protection is to guarantee the presence of the riparian forest, recognized by several researchers [1-3] as fundamental to the watershed environmental balance. Authors such as those of References [4-9] highlight the importance of riparian forests in maintaining ecological balance, in creating an environment for aquatic and riverside life development, feeding and protecting these ecosystems and providing pollination, seed dispersal and nutrient cycling.

The rivers' water flow temperature is an essential attribute of river ecosystems' aquatic and terrestrial habitat [10-12], being mainly determined by heat flows, and the direction 
of energy transfer processes can be profoundly altered by the riparian landscape conditions [13-16]. Bearing in mind that the river's water quality is related to the aquatic ecosystem stability, changes in river temperature can alter the balance and generate mortality events [17-19], contributing to the deterioration of this environment.

Another critical parameter in the water balance of riparian zones is humidity. Infiltration [20] and water absorption by the litter increase microbial metabolic efficiency [21], facilitating nutrient cycling, soil fertility, and, consequently, establishing the riparian forest. Due to the soil's hydraulic properties [22,23], the vegetation cover increases the water storage capacity in the micro basins, stabilizes, and regulates the flow of rivers in the dry seasons. Besides, it is essential to improve the quantity and quality of the water resource and recharge the aquifers [24,25], in addition to acting as a pollutant filter, slope stabilizer and carbon fixers [26-28].

However, tropical streams, such as those existing in Brazil, present themselves as one of the most threatened with the reduction of riparian forest [29-31], mainly the small headwater streams, which are fragile ecosystems and are highly susceptible to anthropogenic impacts [32]. Alterations in these areas expose the water-receiving bodies downstream to upstream activities' cumulative effects [33,34]. The riparian vegetation degradation is one of the main risk factors for the hydrological cycle's stability, influencing the surface water runoff. This phenomenon is associated with the use of surface water and protection against the effects of its displacement, such as sediment transport, speed flow and flow of the water body [35-37]. Experiments in river channels have shown that vegetation acts as a factor to reduce drag coefficient, erosion and general disturbance in the channel bed [38], and points to a significant influence of the riparian vegetation structure in the margin profile [39].

Anthropic impacts on riparian forests, including deforestation, fires, erosion [40], mining, invasion of exotic species, pollution by fertilizers and pesticides [41-43], changes by water abstraction and use of riverside lands, associated with the effects of climate change [44-47], have increased the likelihood of these ecosystems' degradation [48,49]. However, the determining factor in the riparian forest degradation is habitats' fragmentation $[7,50]$, the main consequence of which is the reduction of biotic diversity [24,51-58].

Considering that a significant portion of the riparian forest in the Brazilian Atlantic Forest biome has suffered growing deforestation over the last decades, initiatives must be taken to restore this forest. A significant portion of the rivers FMP in the Eastern Region of Brazil is segmented into stretches with specific characteristics that influence reforestation success. This scenario is also faced by the Jacaré River, whose hydrographic basin is located in the Minas Gerais state's center-west. Fragmentation situations such as that of the Jacaré River are frequently found in several Brazilian hydrographic basins. They represent a big challenge for Brazilian managers since reforestation actions demand volumes of investments that are difficult to meet in the face of the country's economic crisis. It is essential to identify the reforestation areas with the most significant potential for success in this context, which requires using methodologies that consider these areas' characteristics and increase the selection process' effectiveness.

In a context in which anthropic impacts and the effects of climate change negatively influence the quality and quantity of water resources, and the riparian forest fragmentation impairs its ability to mitigate the consequences of these adverse effects, the purpose of this research was to use a methodology integrating Geographic Information System (GIS), fuzzy logic, Analytic Hierarchy Process (AHP) and sensitivity analysis to model the FMP stretches selection that presents the best conditions for riparian forest reforestation using a real case, the Jacaré river basin, whose characteristics are often seen in Brazilian watersheds.

In a scenario of the scarcity of public resources resulting from the financial crises faced by Brazil and by a significant portion of the underdeveloped and developing countries, we hope that this work will contribute so that managers can direct their efforts towards reforestation actions with better chances of success, thus collaborating to help terrestrial ecosystems survive and improve water resource quality. 


\section{Materials and Methods}

\subsection{The Context of Using GIS, Fuzzy Logic, AHP and Sensitivity Analysis}

To support the decision-making process on FMP stretches that present the best reforestation conditions, we use a spatial analysis approach based on Geographical Information Systems (GIS). GIS is a set of tools for inputs, storage and retrieval, manipulation, analysis and spatial data outputs [59]. There are plenty of examples of GIS use in the literature to identify areas that meet specific criteria, mainly because it allows overlapping information from digital maps. However, this functionality has some limitations when dealing with non-deterministic nature information, which occurs mainly due to three situations: (a) When it is necessary to analyze more than four or five variables, the digital maps overlays are difficult to understand, (b) in cases where the variables are not equally important, the overlapping procedures in the GIS usually do not adequately consider the relative importance between the variables and (c) when the threshold values defined for the variables that will be analyzed by overlap is a problem that strongly influences the result of the area tracking. Also, threshold values for continuous variables on a nominal basis usually imply substantial losses of information.

One way to deal with these limitations is to use methods that consider the multicritical and nebulous nature of the decision-making process, such as incorporating multicriteria analysis [60-65] and Fuzzy logic [66-68]. The multicriteria analysis techniques make it possible to analyze various choice possibilities according to multiple criteria and usually conflicting objectives. Among these techniques, the Analytical Hierarchy Process (AHP) [69] stands out based on a participatory process in which experts evaluate criteria and alternatives, assigning weights according to each one, thus enabling the ranking of alternatives according to their importance. Its application in GIS, concerning the analysis of spatial information, improves the selection process of a specific area, where through a process of map overlay, one has to choose the best solution, through analysis of a set of alternatives and attributes in which conflicting points of view and objectives are also considered [70].

In a GIS environment, through multicriteria analysis, geographic data and stakeholder preferences are combined to provide quantified values for assessments and other decisions [71]. Through this approach, spatial data are combined and transformed into final maps according to decision rules that define the relationships between the input data and the final maps [59]. In practice, multicriteria analysis optimizes and increases the selection process's effectiveness for a specific area concerning spatial information analysis. Thus, we have to choose the best solution through a map overlay process by analyzing a set of alternatives and attributes in which conflicting points of view and objectives are also considered [70].

Although AHP has mechanisms to identify and reduce the experts' judgment inconsistencies, this is still a critical point of the method. For the AHP results to be completely reliable, it would be necessary for those responsible for the trials to have complete information on the subject, which rarely occurs. This finding is cited as a method weakening [72], as it does not consider the inaccuracies and ambiguities inherent in judgment processes based on human perception. Besides, a significant portion of spatial phenomena shows a degree of vagueness or uncertainty with indeterminate limits, and the process of prioritizing regions due to their ability to meet specific criteria does not have a Boolean character, but rather diffuse, since it expresses various degrees of association of a set. In this context, fuzzy logic has been used in several GIS applications, such as fuzzy spatial analysis, fuzzy reasoning and the representation of fuzzy boundaries [66].

In several fields of study, fuzzy logic has been widely used associated with GIS and multicriteria analysis, such as, for example, locating water reservoirs [73], urban planning [74], flood risk assessment [75] and landslide susceptibility mapping [76] concerning reforestation. It has also been used in studies related to reforestation, such as, for example, sustainable development of reforestation [77], assessing reforestation placement and benefit for erosion control [78] and forest fire risk [79]. 
To deal with the inaccuracies and ambiguities of the judgment processes, we used fuzzy set theory $[73,80,81]$ so that, instead of a number representing a judgment, intervals could be used appropriately\{72\}. Jiang and Eastman [82] present the main reasons for the use of fuzzy set membership in criteria standardization, which in summary are: (1) It provides a solid logic for the standardization process, and (2) the logic of fuzzy sets bridges a significant gap between Boolean assessment and continuous scaling in the weighted linear combination. Thus, the fuzzy approach makes it possible that human judgment's ambiguities and uncertainties involving decision-making regarding multiple criteria can be adequately considered.

Using GIS to identify areas that meet specific criteria results in an overlay map that classifies the evaluated region areas according to their importance. However, even with the AHP mechanisms to reduce and identify experts' judgment inconsistencies and the fuzzy logic's ability to deal with human judgment's inaccuracies and ambiguities, there is still a risk of inconsistencies. Possible variations of the weights provided by Fuzzy AHP can influence the assessment of which areas are part of a particular class of importance.

In this context, we decided to evaluate the modeling's validity by performing a sensitivity analysis based on the weights' variation in a predefined interval. In this sense, we use the One-At-a-Time (OAT) method [83,84]. Thus, we investigated the weights' sensitivity attributed to the maps that represent the criteria evaluated by the specialists, varying the influence of each weight separately, and keeping the others unchanged. This approach of producing summary sensitivity indices for the study area is strongly recommended by the authors of Reference [85].

Finally, we decided to check if the overlay map characteristics were compatible with the literature on the topic and with the data from the input layers to confirm the methodology's effectiveness. Table 1 shows the procedures used to increase the methodology reliability.

Table 1. Procedures used to increase the methodology reliability.

\begin{tabular}{|c|c|c|}
\hline Action & Occurrence & Procedure \\
\hline $\begin{array}{l}\text { Selection of the main factors of riparian } \\
\text { forests' reforestation success }\end{array}$ & $\begin{array}{l}\text { Some important factors are not being } \\
\text { identified }\end{array}$ & $\begin{array}{l}\text { Broad and detailed bibliographic research } \\
\text { using a widely used systematic reviews } \\
\text { method: PRISMA (Preferred Reporting } \\
\text { Items for Systematic Reviews and Meta } \\
\text { Analyses) }\end{array}$ \\
\hline $\begin{array}{l}\text { Establishment of weights for the factors } \\
\text { according to the relative importance } \\
\text { between them }\end{array}$ & $\begin{array}{l}\text { The complexity of interrelated } \\
\text { alternatives selection } \\
\text { Inconsistencies of the pairwise } \\
\text { comparisons matrix } \\
\text { - Inaccuracies and ambiguities were } \\
\text { inherent in judgment processes } \\
\text { based on human perception }\end{array}$ & $\begin{array}{l}\text { - Multi-criteria analysis to conduct } \\
\text { the process and evaluate the experts' } \\
\text { judgment consistency } \\
\text { - Fuzzy measure incorporation in } \\
\text { Saaty's fundamental scale }\end{array}$ \\
\hline Input layers aggregation & $\begin{array}{l}\text { Variations in the weights can influence } \\
\text { the assessment of which areas are part of } \\
\text { a particular class of importance. }\end{array}$ & $\begin{array}{l}\text { Use of the One-At-a-Time (OAT) method } \\
\text { to perform sensitivity analysis based on } \\
\text { the variation of the weights in a } \\
\text { predefined interval }\end{array}$ \\
\hline $\begin{array}{l}\text { Methodology effectiveness evaluation in } \\
\text { identifying the best sites }\end{array}$ & $\begin{array}{l}\text { Best sites' characteristics to be } \\
\text { incompatible with the literature on the } \\
\text { topic }\end{array}$ & $\begin{array}{l}\text { Comparing the best sites' characteristics } \\
\text { with those expected, considering the } \\
\text { authors' view of the articles that } \\
\text { supported this work }\end{array}$ \\
\hline
\end{tabular}




\subsection{Methodology Steps}

Our approach involved four steps. In the first, named characterization, we define the study area and the GIS datasets. In the second, named exclusion of unsuitable areas for reforestation, we define the exclusion criteria (constraints) and prepare the constraint map. In the third, named prioritization of areas for reforestation, we select the main drivers of riparian forests' reforestation success, we categorize the criteria used in the AHP, we define the mechanisms for transforming the criteria into spatial information, we establish the procedures of multi-criteria analysis and fuzziness of the judgment and we aggregate the input layers. In the fourth and last stage, called evaluation of the robustness of the results, we use the "the One-At-a-Time (OAT)" method to assess the map weights' sensitivity, and we evaluate the methodology's effectiveness in identifying the best sites by comparing the best sites' characteristics with those expected, considering the authors' view of the articles that supported this work. Figure 1 summarizes the used methodology. In the next sections, we will present a summary of each stage.

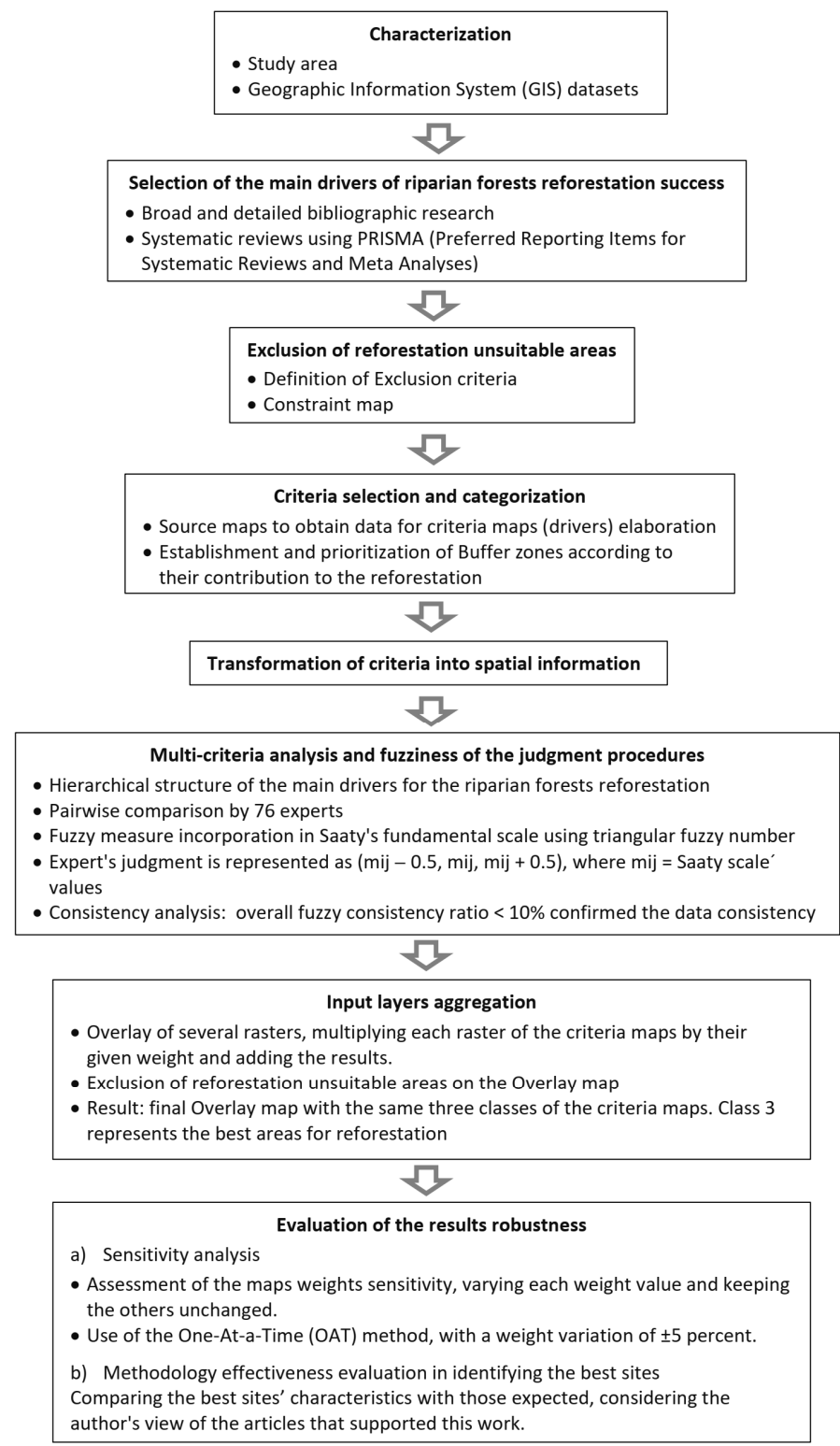

Figure 1. Synthesis of the methodology. 


\subsection{Characterization}

\subsubsection{The Study Area}

The Jacaré River basin area is located in the southeastern macro-region of Brazil and the central-western mesoregion of the state of Minas Gerais (Figure 2). The section of the Rio Jacaré, the object of this study, is comprised between the coordinates $44^{\circ} 32^{\prime} 27^{\prime \prime} \mathrm{W}$ and $20^{\circ} 48^{\prime} 27^{\prime \prime} \mathrm{S}$ upstream, and $45^{\circ} 16^{\prime} 28^{\prime \prime} \mathrm{W}$ and $21^{\circ} 02^{\prime} 41^{\prime \prime} \mathrm{S}$ downstream and has approximately $149 \mathrm{~km}$ in length and $5.0 \mathrm{~km}^{2}$ of water depth (Figure 3). The region presents wavy relief with groups of hills and small mountains or ridges. The region's climate is tropical in altitude with mild summers and cool, dry winters [86], which is characterized by presenting the averages for the coldest month below $18^{\circ}$ and an abundant regime of tropical rains. Its basin is inserted in the Atlantic Forest biome, with characteristic vegetation of tropical broadleaved forest with some Cerrado patches. The original cover of this landscape is in an accelerated process of forest fragmentation. The vegetation has three formations: savanna, field and forest (perennial forests). Human occupation occurs through small urban centers and agricultural production and mineral extraction processes.

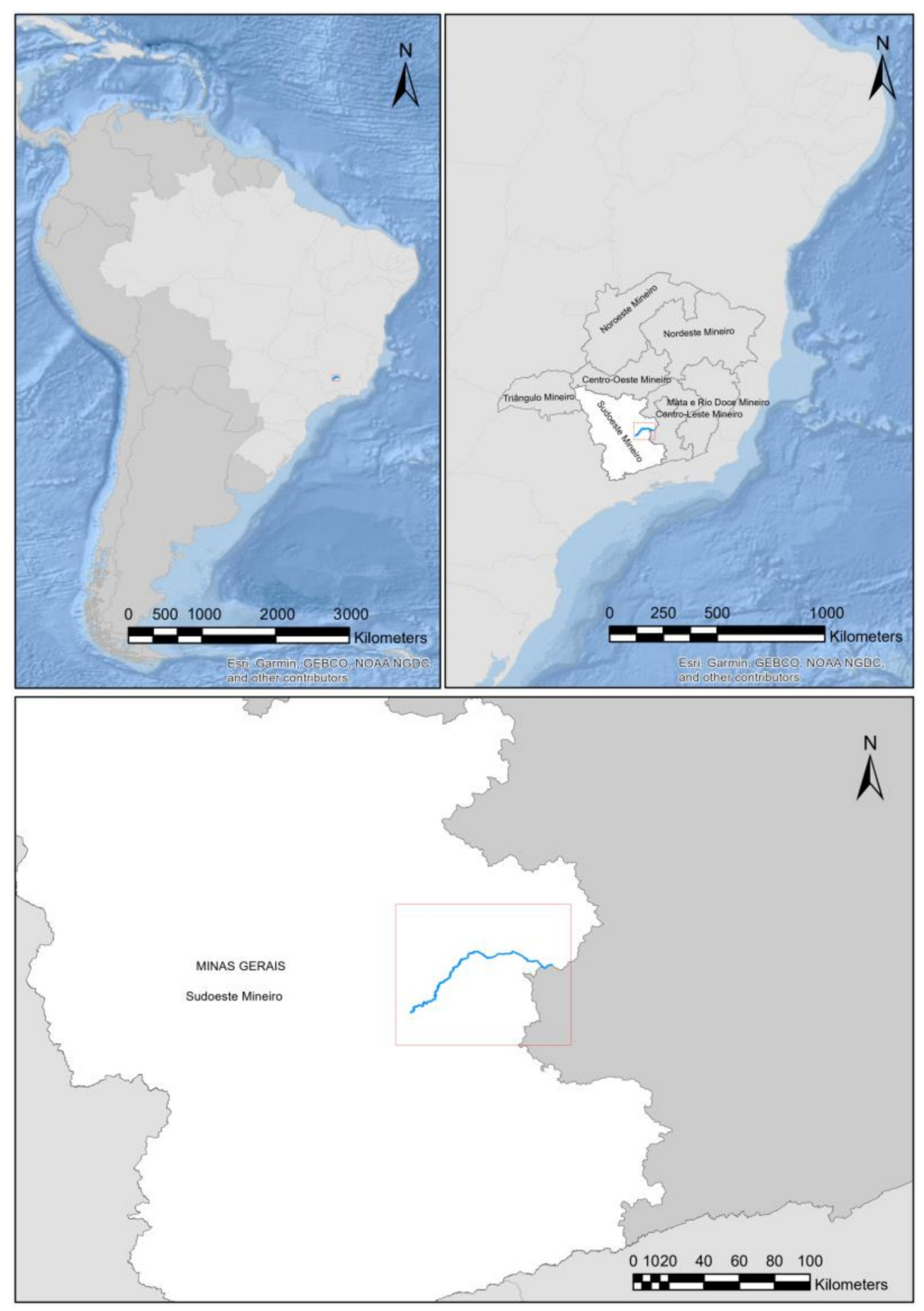

Figure 2. Study area localization. 


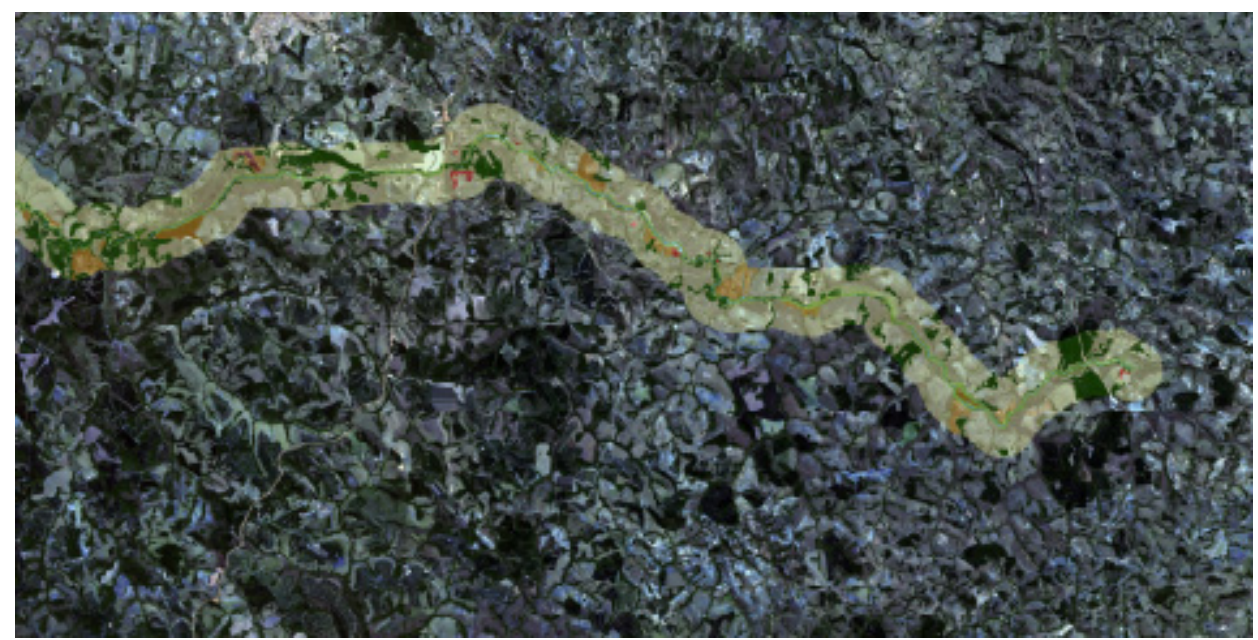

(a)

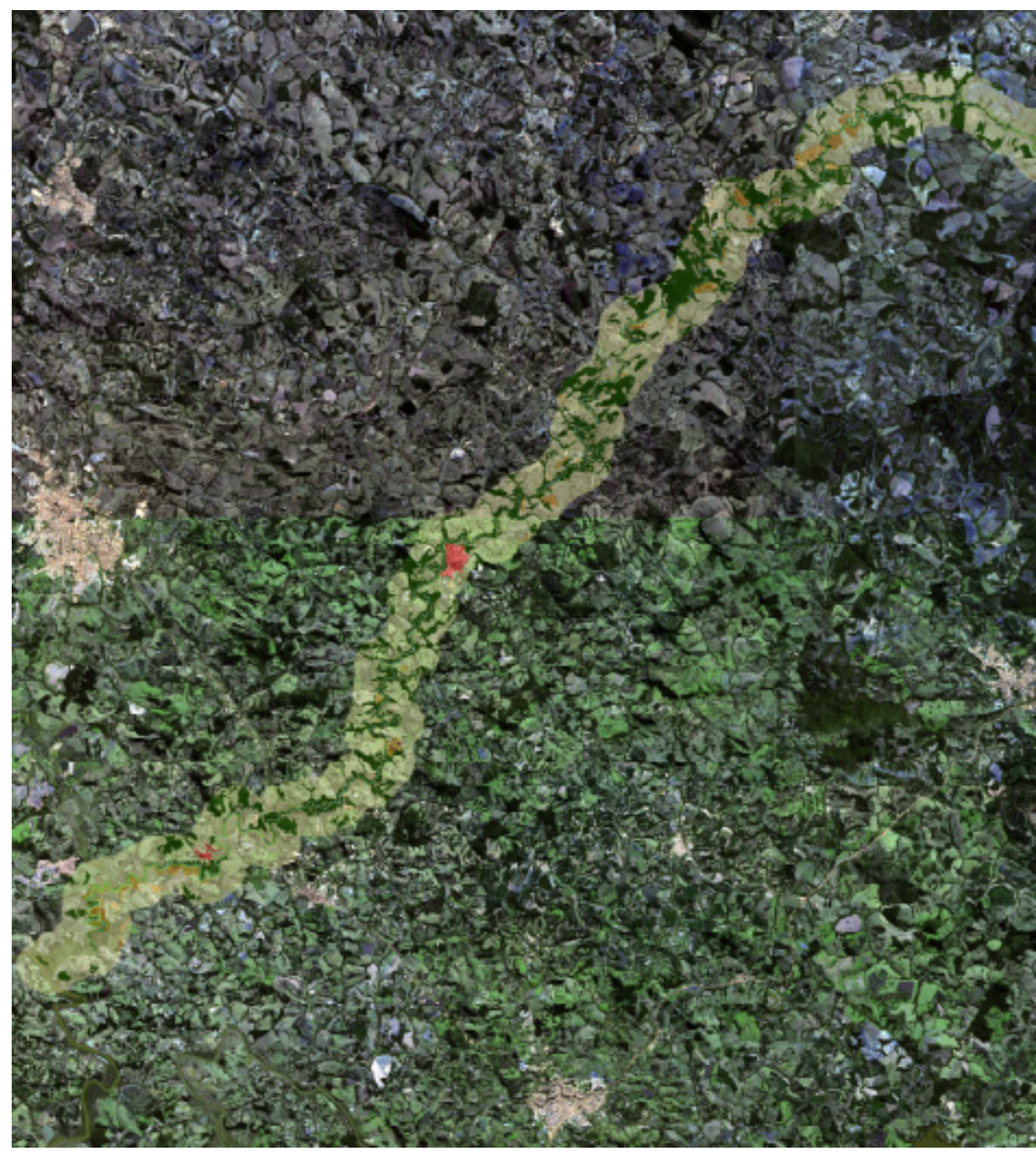

(b)

Figure 3. (a) Study area image-upper river course, (b) study area image-lower river course. 


\subsubsection{GIS Datasets}

The geographic information system data were extracted from the following bases: soil map prepared by the Brazilian Agricultural Research Corporation-EMBRAPA, 2013, on a scale of 1:30,000, from which we extracted information about the soil typology, Digital Elevation Model ALOS PALSAR, $12.5 \mathrm{~m}$ of spatial resolution, used to categorize the riverbank slopes, and 2018 Sentinel 2 satellite image, with $10 \mathrm{~m}$ spatial resolution and 16 bits radiometric resolution, which was used to produce the land use and coverage map and to categorize the restrictions, the distance from the forest fragment to the riverbank, the forest fragment vulnerability and the forest cover typology.

\subsection{Selection of Drivers for the Success of Reforestation of Riparian Forests}

For the selection of the main drivers that influence reforestation success, we carried out a broad and detailed bibliographic research on the Web of Science, Scopus, Scielo and on the websites of the leading scientific publishers, considering articles published in the last ten years and adopting the recommendations of the Preferred Reporting Items for Systematic Reviews and Meta Analyses (PRISMA). The keywords used were riparian forest, riparian afforestation, riparian reforestation, water sustainability and water quality. Initially, we performed an exploratory reading from a brief reading of titles and abstracts to exclude articles that did not directly correlate with the covered topics. Then, we performed a selective reading on the selected articles to exclude those that did not provide relevant primary information for the topics covered. As a result, 123 articles were selected. The reference consultation initially identified 17 recurrent variables that interfere with the success of riparian reforestation. Among the variables found, 12 were dependent on other variables, thus, they were aggregated into five large groups, which represent the synergy of the variables initially found. This work seeks to present a method/methodology that can be applied by the greatest number of managers in countries where environmental data are scarce or nonexistent. Therefore, the reduction in the number of variables chosen, without losing their effectiveness, took into account the ease of obtaining environmental bases by the managers of riparian reforestation projects. Some of the variables initially identified have specific characteristics that are impossible to be geospatialized and thus are presented as suggestions to be followed by professionals in the area of riparian reforestation projects. These drivers are:

(a) Soil: Soil is an essential factor for reforestation success. Its characteristics determine the degree of colonization, establishment and development of planted seedlings. Characteristics such as the amount of moisture, nutrients and soil granulometry affect the germination of seeds and the growth rate and survival rate of seedlings $[87,88]$. The different tree species differ in terms of nutrient requirements, and, in general, the requirement is related to the fertility of the area where the species grow and are adapted [89-91]. Thus, the fertility levels related to the aluminum concentration and chemical bases existing in the soil allow for identifying inadequate concentrations that may limit planting forest seedlings' productivity. In this context, the soil classification is made, in the study region, considering that the eutrophic soil has null or reduced aluminum and good fertility, the dystrophic soil is a medium-fertility soil and the acric soil is generally of low fertility and acid [92]. The presence of eutrophic soil in areas to be reforested collaborates for success in forest seedlings' growth.

(b) Vegetation: The type of vegetation in the area to be reforested is an essential factor for riparian reforestation success. The vegetation cover in these areas increases fertility, conserves moisture, protects against soil loss and promotes the microorganisms' establishment that accelerates seedlings' growth. The most common situations are:

- Bare soil, which is areas without vegetation, with reduced fertility and intense evaporation process, in addition to low humidity. They present exposure of mineral aggregates, laminar erosion by grooves and gullies. It is usually associated with the strong use of extensive livestock. 
- Grass, which are areas of herbaceous or shrubby vegetation, being rich in grasses and legumes. They have relative humidity and soil fertility. However, there is a competition between species, hindering the regeneration process. They are generally used in livestock activities, burdening and endangering the reforestation process.

- Regeneration vegetation, which are areas in the FMP that present anthropic vegetation, develops from species growth that naturally regenerates in agricultural systems or after their abandonment. The humidity and fertility of riparian areas contribute to the development of this type of vegetation, with semi-dense characteristics and with the occurrence of laminar erosions $[93,94]$. The regeneration vegetation occurrence in areas to be reforested collaborates to increase the riparian forest.

(c) Slope: The reforestation site's slope is directly associated with soil stability and changes in its properties, particularly in the water regime and fertility. Less inclined soils facilitate the creation of microsites that aid the fixation and germination of seeds $[95,96]$. Tests carried out in Reference [97] in tropical forest restoration observed the fastest growth of forest seedlings on slopes that are less steep. The author of Reference [97] describes the high seedling mortality that he observed on steeper slopes due to the increase of the soil organic matter through the decreasing slope, increasing the available phosphorus in the soil in shallower slopes $[97,98]$. Less inclined slopes are more efficient for forest seedlings, lower cost of planting, better management of the area and consequent success in reforestation.

(d) Distance from the forest fragment to the reforestation sites: The landscape spatial configuration influences local ecological processes [99,100]. In fragmented landscapes, forest fragments provide havens for many forest species and potential seeds for reforestation [101-103]. The proximity of forest fragments close to the reforestation sites facilitates the colonization process of these areas by local species since the majority of non-implanted species will depend on neighboring sources through the dissemination of seeds [104-106]. Factors linked to biological flows, such as seed dispersal, interfere with the dynamics of the reforestation process to contribute to the forest system sustainability to be installed [104,105,107-110]. Besides, the distance of seed dispersal has a significant influence on the persistence of species in forest fragments [111], on the vegetation recovery in altered areas [112] and on the migration of vegetation through landscapes fragmented in response to climate change $[105,106,113,114]$. Thus, the less vulnerable a forest fragment is, the more significant its contribution to reforestation success.

(e) Adjacent forest fragments' vulnerability: The vulnerability degree assessment of forest fragments aims to determine the structural, spatial and temporal patterns of these fragments [115], which helps to identify the priority areas for recomposing the riparian forest [116]. The fragment vulnerability is associated with its total area since the biodiversity sources' size and quality in the fragment core decrease when the fragment area becomes smaller than the minimum areas necessary for populations' survival [117]. It influences the richness of species contributing to the reforestation site [104-106]. Fragments with smaller areas are susceptible to more significant changes in the matrix dynamics where they are inserted [118]. The external portion of the fragment adjacent to the border becomes part of the transition zone, causing microclimate changes, such as increased temperature and water stress, and changes in species composition and vegetation structure. In this sense, the increased effect at the fragment's edge leads to constant forest reduction, generating a greater vulnerability. It reduces the richness and abundance of adult species and seedlings [118-120], affecting the colonization process' efficiency of adjacent areas. The eastern Brazilian region forest landscape's current Atlantic conformation has many small forest fragments [121].

\subsection{Exclusion of Reforestation Unsuitable Areas}

In this step, we define the exclusion criteria (constraints) to exclude the unsuitable reforestation areas. The constraints adopted were forest areas (primary vegetation), rocky outcrop areas, anthropic pressure areas and areas with a slope equal to or greater than $45^{\circ}$. 
For these areas, we assigned an index value of " 0 " to represent its inadequacy and an index value of " 1 " for the other areas.

(a) Forest areas (primary vegetation): They encompass dense vegetation areas with soil free from erosion, already having a significant biological diversity, with the effects of anthropic actions being minimal, to the point of not significantly affecting their original structure characteristics, species and water production. Areas with these characteristics do not require reforestation, given their essential contribution to the water resource's quantity and quality in the Hydrographic Basin.

(b) Rocky outcrops areas: It presents an almost complete absence of vegetation cover from the soil, a high evaporation degree and insolation, in addition to heterogeneous topography. On these outcrops, usually, there is the establishment of vegetation cover distinct from the adjacent area, especially adapted to this type of environment. In this way, these environments do not support forest species' planting, presenting a critical limiting factor in the reforestation processes [122].

(c) Anthropic pressure areas: We considered the areas with highways, railways and urban agglomerations. Forest fragments close to urban agglomerations and easily accessible attract people, and urban animals, exposing the forest fragment to a high level of stress $[123,124]$. These factors impact riparian reforestation success as they present risks of fires, deforestation and pollution caused mainly by transportation, electrical networks and human negligence. Thus, we adopted a buffer zone of $50 \mathrm{~m}$ for highways and $100 \mathrm{~m}$ for urban areas.

(d) Areas with a slope equal to or greater than $45^{\circ}$ : These areas offer greater susceptibility to erosive processes, loss of nutrients and difficult access. According to Brazilian legislation [125], they must be considered Permanent Preservation Areas and preserved by law. The soil's slope is a limiting factor of most significant importance in reforestation projects [122].

(e) Areas from $1000 \mathrm{~m}$ from the river axis: These areas were excluded given that they have little importance in the regeneration process of riparian areas to be reforested, taking into account the density of significant forest fragments that occur inside the buffer [126], associated with the influence of seed rain, a process by which forest seeds are dispersed over varying distance [127]. The seed rain acts in the seed bank's construction that corresponds to the seeds' areas awaiting the necessary conditions for their germination. In open areas, seed rain occurs differently over shrub associations, as well as over isolated trees, and can be considered facilitators of forest species colonization over pasture areas [128].

\subsection{Prioritization of Areas for Reforestation}

\subsubsection{Criteria Selection and Categorization}

The criteria used in the AHP were the drivers presented in Section 2.4. Figure 4 shows the hierarchical structure of the criteria.

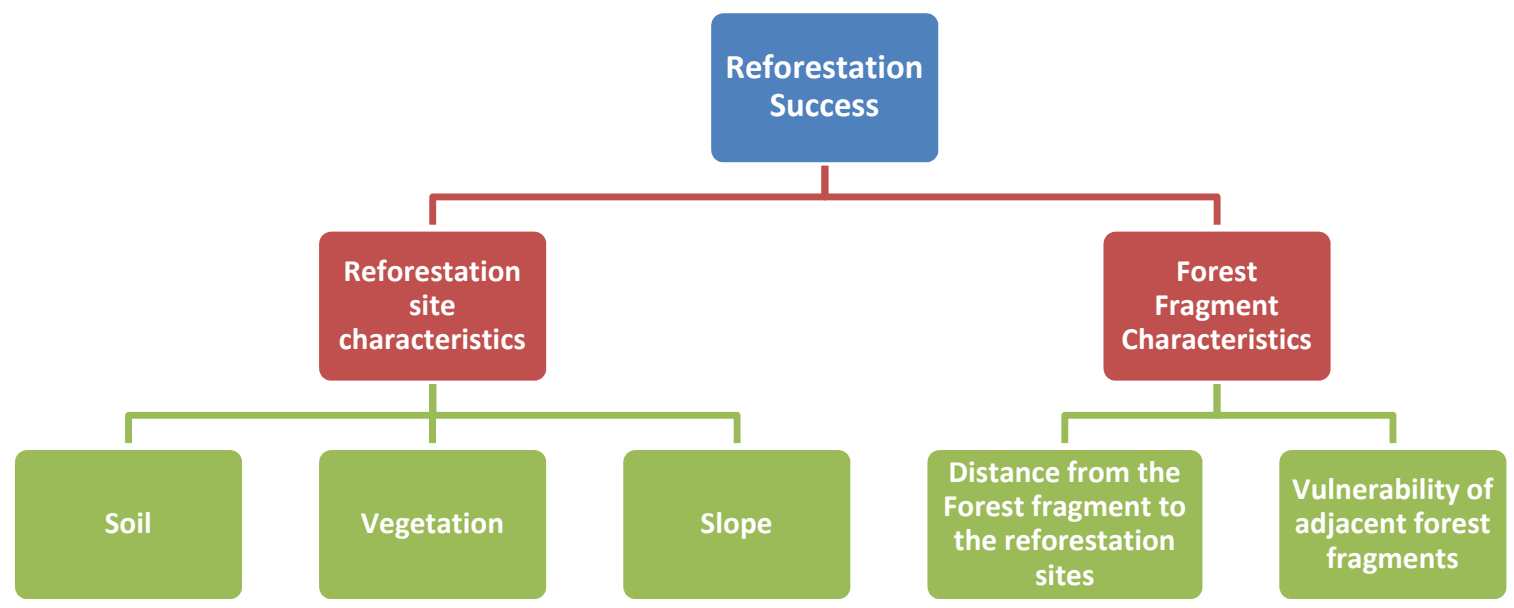

Figure 4. The hierarchical structure of the criteria. 
We established a gradation ranging from 1 to 3 for each criterion, according to their contribution to the reforestation success (Table 2). Class 3 represents the areas with high potential for reforestation success.

Table 2. Summary of the input layers.

\begin{tabular}{|c|c|c|c|}
\hline Layer Name & Source Map & Buffer Zone & Classes \\
\hline \multirow{3}{*}{ Slope } & \multirow{3}{*}{$\begin{array}{l}\text { ALOS PALSAR DTM image } \\
\text { with } 12.5 \mathrm{~m} \text { resolution. }\end{array}$} & $\leq 15 \%$ & 3 \\
\hline & & $>15 \% \leq 30 \%$ & 2 \\
\hline & & $>30 \% \leq 100 \%$ & 1 \\
\hline \multirow{3}{*}{ Soil } & \multirow{3}{*}{$\begin{array}{l}\text { EMBRAPA Geological Map } \\
\text { 1:30,000 }\end{array}$} & Eutrophic & 3 \\
\hline & & Dystrophic & 2 \\
\hline & & Acric & 1 \\
\hline \multirow{3}{*}{ Vegetation } & \multirow{3}{*}{$\begin{array}{l}\text { Satellite image: Sentinel-2 } \\
\text { with } 10 \mathrm{~m} \text { spatial resolution. }\end{array}$} & Regeneration Vegetation & 3 \\
\hline & & Grass & 2 \\
\hline & & Bare soil & 1 \\
\hline \multirow{3}{*}{ Vulnerability of adjacent forest fragments } & \multirow{3}{*}{$\begin{array}{l}\text { Satellite image: Sentinel-2 } \\
\text { with } 10 \mathrm{~m} \text { spatial resolution. }\end{array}$} & $\begin{array}{l}\text { Fragments that go beyond the } \\
\qquad 100 \mathrm{~m} \text { buffer }\end{array}$ & 3 \\
\hline & & The other fragments & 2 \\
\hline & & Fragments in the $50 \mathrm{~m}$ buffer & 1 \\
\hline \multirow{3}{*}{$\begin{array}{l}\text { Distance from the forest fragment to the } \\
\text { reforestation sites }\end{array}$} & \multirow{3}{*}{$\begin{array}{l}\text { Satellite image: Sentinel-2 } \\
\text { with } 10 \mathrm{~m} \text { spatial resolution }\end{array}$} & Low $(0$ to $150 \mathrm{~m})$ & 3 \\
\hline & & Average (150 to $500 \mathrm{~m}$ ) & 2 \\
\hline & & High (500 to $1000 \mathrm{~m}$ ) & 1 \\
\hline
\end{tabular}

\subsubsection{Transformation of Criteria into Spatial Information}

We adopted the following procedures for the slope and soil type maps' elaboration:

- Slope: Based on the Digital Elevation Model (DEM), ALOS, with 12.5 m of spatial resolution, from 2015, we used the Slope function to convert altitude information into the slope, and the Reclassify function to delimit the slope strips depending on their influence on the success of reforestation.

- Soil: From the soil classification vector map of the Brazilian Agricultural Research Corporation [129], we used the Merge function to classify the different soil types, grouping them into three classes: eutrophic, dystrophic and uncritical [92].

For the other maps, we adopted the following procedures:

- Land use and cover map: The Sentinel 2, 2018 image, $10 \mathrm{~m}$ of the 16-bit radiometric resolution, was used to make this map. Using the Classification function, we identified the pixel information and, using the Training Sample Manager function, the pixels were grouped into classes, generating a spectral signature file. In this way, the Assisted Semi-Automatic Vectorization process was applied. We use the Classification function to classify the different elements of the image. In this way, the features that composed it were vectored, providing the following maps: vegetation, vulnerability of adjacent forest fragments to reforestation sites, distance from the forest fragment to the reforestation sites and constraint map.

- Vulnerability of adjacent forest fragments to reforestation sites: We used the Feature to Point tool to identify each fragment's central point and the Join Data tool to attach each fragment's measures to their respective central points. To determine the degree of vulnerability, we used buffers of $50 \mathrm{~m}$ and $150 \mathrm{~m}$. Fragments in the 50 $\mathrm{m}$ buffer were considered highly vulnerable, those extrapolated in the $150 \mathrm{~m}$ buffer 
were considered low vulnerability and the remaining fragments were regarded as medium vulnerability.

- Distance from the forest fragment to the reforestation sites: We created distance classes from the central points of each fragment to classify the fragment according to the buffer in which its central point was inserted. We used buffers along the river with a distance of 0 to $150 \mathrm{~m}$ (Low), from 150 to $500 \mathrm{~m}$ (Average) and above $500 \mathrm{~m}$ (High).

- Vegetation: We used the Select by Attribute tool to extract the areas of forest, pasture and exposed soil from the land use and cover map.

- Constraints: We converted the vector data layers to the raster model to create a Boolean map. We assigned "pixel to pixel," the index " 1 " for the areas considered suitable for reforestation, and " 0 " for the inadequate areas.

\subsubsection{Establishment of Multi-Criteria Analysis and Fuzziness of the Judgment Procedures}

AHP [69] is based on pairwise comparison matrices to establish the relative importance of a set of criteria as a function of weights. Thus, after establishing the hierarchical structure (Figure 4), we established weights for the criteria according to their relative importance by comparing each criterion pairwise with the others.

For determining the relative importance among the criteria, we used the Participatory Technique [130]. We consulted 76 specialists from public agencies, research centers and specialized companies who work in ecosystem conservation, hydrology, geoprocessing, geology and climatology. In AHP, as originally proposed in Reference [130], the pairwise comparison was performed considering a scale of integers ranging from 1 to 9 (Table 3), which express one criterion's dominance over the other. For elaborating the pairwise comparison matrices, we used a form that followed the format generally used in surveys using the AHP method: in the rows and columns, the criteria, and in the cells, the value of the judgment.

Table 3. Saaty's fundamental scale [131].

\begin{tabular}{cc}
\hline Numerical Scale & Verbal Scale \\
\hline 1 & Equal importance \\
3 & Moderate importance \\
5 & Strong importance \\
7 & Very Strong importance \\
9 & Extreme importance \\
$2,4,6,8$ & Intermediate values \\
& If an activity has one of the above numbers \\
Reciprocals of above non-zero numbers & (e.g., 5) compared with a second activity, then \\
& the second activity has the reciprocal value \\
& when compared to the first (i.e., 1/5). \\
\hline
\end{tabular}

To deal with the inaccuracies and ambiguities inherent in judgment processes based on human perception we use fuzzy set theory $[73,80,81]$ so that instead of a number representing a judgment, intervals can be used appropriately. In this sense, we used the special class of fuzzy numbers called triangular fuzzy numbers (TFN), in which a fuzzy number can be characterized by a $\mu_{A}(x)$ membership function that assumes values in the range $(0,1)$. Figure 5 and Equation (1) respectively, graphically and mathematically represent the triangular membership function:

$$
\mu_{A}(x)= \begin{cases}0 & x<l \\ \frac{x-l}{m-l} & l \leq x \leq m \\ \frac{u-x}{u-m} & m \leq x \leq u \\ 0 & x>u\end{cases}
$$




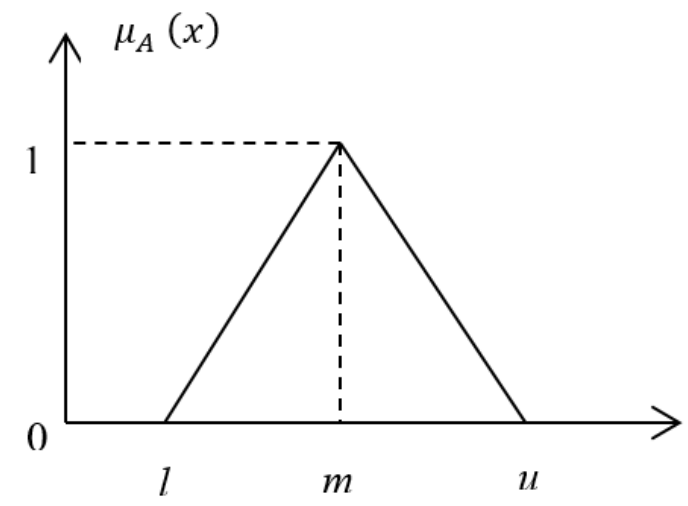

Figure 5. Membership function of a triangular fuzzy number $M=(1, m, u)$.

Thus, a TFN referring to a specialist's judgment is represented as $\left(l_{i j}, m_{i j}, u_{i j}\right)$, where $l_{i j}=$ lower limit, $m_{i j}=$ modal value (one of the values of the Saaty scale) and $u_{i j}=$ upper limit.

Considering two TFNs, $\mathrm{A}=\left(l_{1}, m_{1}, u_{1}\right)$ and $\mathrm{B}=\left(l_{2}, m_{2}, u_{2}\right)$, among the various operations that can be performed, three important operations will be used in this article:

(i) Addition : $\mathrm{A} \oplus \mathrm{B}=\left(l_{1}, m_{1}, u_{1}\right) \oplus\left(l_{2}, m_{2}, u_{2}\right)=\left(l_{1}+l_{2}, m_{1}+m_{2}, u_{1}+u_{2}\right)$

(ii)Multiplication : $\mathrm{A} \otimes \mathrm{B}=\left(l_{1}, m_{1}, u_{1}\right) \otimes\left(l_{2}, m_{2}, u_{2}\right)=\left(l_{1} l_{2}, m_{1} m_{2}, u_{1} u_{2}\right)$

(iii)Inverse : $\left(l_{1}+m_{1}+u_{1}\right)^{-1}=\left(1 / u_{1}, 1 / m_{1}, 1 / l_{1}\right)$

The values of $l_{i j}$ and $u_{i j}$ represent the fuzziness of the judgment, which is influenced by the degree of fuzziness $(\delta)$, where, for symmetric $\mu_{A}(x)$ membership function, $\delta=m_{i j}$ $-l_{i j}=u_{i j}-m_{i j}$. Thus, considering the range 1 to 9 of the Saaty's scale, the fuzzy numbers (which represent a fuzzy judgment) can be represented as follows:

$$
\begin{gathered}
\left(l_{i j}, m_{i j}, u_{i j}\right)=\left(m_{i j}-\delta, m_{i j}, m_{i j}+\delta\right) \text { for } i \neq j \\
\left(l_{i j}, m_{i j}, u_{i j}\right)^{-1}=\left(1 /\left(m_{i j}+\delta\right), 1 / m_{i j}, 1 /\left(m_{i j}-\delta\right)\right) \text { for } i \neq j \\
\left(l_{i j}, m_{i j}, u_{i j}\right)=(1,1,1+\delta) \text { for } i \neq j \text { and } m=1 \\
\left(l_{i j}, m_{i j}, u_{i j}\right)=(9-\delta, 9,9) \text { for } i \neq j \text { and } m=9
\end{gathered}
$$

\begin{tabular}{|c|c|c|c|}
\hline Saaty's Scale & Verbal Scale & Membership Function & $(l, m, u)$ \\
\hline \multicolumn{3}{|c|}{ Just equal } & $(1.0,1.0,1.0)$ \\
\hline 1 & Equal importance & $\mu_{A}(x)=(2-\mathrm{x}) /(2-1)$ for $1 \leq x \leq 2$ & $(1.0,1.0,1,5)$ \\
\hline 2 & Equal to Moderate & $\begin{array}{l}\mu_{A}(x)=(x-1) /(2-1) \text { for } 1 \leq x \leq 2 \\
\mu_{A}(x)=(3-\mathrm{x}) /(3-2) \text { for } 2 \leq x \leq 3\end{array}$ & $(1.5,2.0,2.5)$ \\
\hline 3 & Moderate importance & $\begin{array}{l}\mu_{A}(x)=(\mathrm{x}-2) /(3-2) \text { for } 2 \leq x \leq 3 \\
\mu_{A}(x)=(4-\mathrm{x}) /(4-3) \text { for } 3 \leq x \leq 4\end{array}$ & $(2.5,3.0,3.5)$ \\
\hline 4 & Moderate to Strong & $\begin{array}{l}\mu_{A}(x)=(x-3) /(4-3) \text { for } 3 \leq x \leq 4 \\
\mu_{A}(x)=(5-x) /(5-4) \text { for } 4 \leq x \leq 5\end{array}$ & $(3.5,4.0,4.5)$ \\
\hline 5 & Strong importance & $\begin{array}{l}\mu_{A}(x)=(x-4) /(5-4) \text { for } 4 \leq x \leq 5 \\
\mu_{A}(x)=(6-x) /(6-5) \text { for } 5 \leq x \leq 6\end{array}$ & $(4.5,5.0,5.5)$ \\
\hline 6 & Strong to Very Strong & $\begin{array}{l}\mu_{A}(x)=(x-5) /(6-5) \text { for } 5 \leq x \leq 6 \\
\mu_{A}(x)=(7-x) /(7-6) \text { for } 6 \leq x \leq 7\end{array}$ & $(5.5,6.0,6.5)$ \\
\hline 7 & Very Strong importance & $\begin{array}{l}\mu_{A}(x)=(x-6) /(7-6) \text { for } 6 \leq x \leq 7 \\
\mu_{A}(x)=(8-x) /(8-7) \text { for } 7 \leq x \leq 8\end{array}$ & $(6.5,7.0,7.5)$ \\
\hline 8 & Very Strong to Extreme & $\begin{array}{l}\mu_{A}(x)=(x-7) /(8-7) \text { for } 7 \leq x \leq 8 \\
\mu_{A}(x)=(9-x) /(9-8) \text { for } 8 \leq x \leq 9\end{array}$ & $(7.5,8.0,8.5)$ \\
\hline 9 & Extreme importance & $\mu_{A}(x)=(\mathrm{x}-8) /(9-8)$ for $8 \leq x \leq 9$ & $(8.5,9.0,9.0)$ \\
\hline \multicolumn{2}{|c|}{ Reciprocals of the above numbers } & & $A_{1}^{-1} \approx\left(1 / u_{i j}, 1 / m_{i j}, 1 / l_{i j}\right)$ \\
\hline
\end{tabular}

The fuzzy measure incorporation in Saaty's fundamental scale, considering Equations (1) and (2) and adopting $\delta=0.5$, can be seen in Table 4.

Table 4. Fuzzy measure incorporation in Saaty's fundamental scale. 
Thus, the fuzzy judgment matrices (FJM) built from pairwise comparisons can be represented as follows:

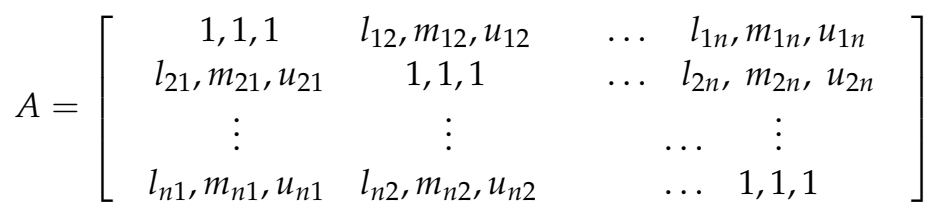

Considering that for each specialist $(r)$ who answered the questionnaire, there will be an FJM, it is necessary to calculate the FJMC that consolidates the pairwise comparisons of all specialists, which was done using the following equations:

$$
\left[\begin{array}{cccc}
1,1,1 & \frac{\sum_{r=1}^{k} l_{12 r}}{k}, \frac{\sum_{r=1}^{k} m_{12 r}}{k}, \frac{\sum_{r=1}^{k} u_{12 r}}{k} & \ldots & \frac{\sum_{r=1}^{k} l_{1 n r}}{k}, \frac{\sum_{r=1}^{k} m_{1 n r}}{k}, \frac{\sum_{r=1}^{k} u_{1 n r}}{k} \\
\frac{\sum_{r=1}^{k} l_{21 r}}{k}, \frac{\sum_{r=1}^{k} m_{21 r}}{k}, \frac{\sum_{r=1}^{k} u_{21 r}}{k} & 1,1,1 & \ldots & \frac{\sum_{r=1}^{k} l_{2 n r}}{k}, \frac{\sum_{r=1}^{k} m_{2 n r}}{k}, \frac{\sum_{r=1}^{k} u_{2 n r}}{k} \\
\vdots & \vdots & & \ldots \\
\frac{\sum_{r=1}^{k} l_{n 1 r}}{k}, \frac{\sum_{r=1}^{k} m_{n 1 r}}{k}, \frac{\sum_{r=1}^{k} u_{n 1 r}}{k} & \frac{\sum_{r=1}^{k} l_{n 2 r}}{k}, \frac{\sum_{r=1}^{k} m_{n 2 r}}{k}, \frac{\sum_{r=1}^{k} u_{n 2 r}}{k} & & \ldots \\
\vdots
\end{array}\right]
$$

To determine the FJMC criteria weights, we used the Fuzzy Extent Analysis (FEA) method [73,132-134]. Thus, we initially calculated the fuzzy synthetic extent $\left(S_{i}\right)$, which corresponds to the normalized values of FJMC row sums [73]. Thus, for each criterion, the respective $\mathrm{Si}$ was calculated using the following equation:

$$
S_{i}=\sum_{j=1}^{n} a_{i j} \otimes\left[\sum_{k=1}^{n} a_{i j} \sum_{j=1}^{n} a_{k j}\right]^{-1}
$$

where:

$$
\sum_{j=1}^{n} a_{i j}=\left(\sum_{j=1}^{n} l_{i j}, \sum_{j=1}^{n} m_{i j}, \sum_{j=1}^{n} u_{i j}\right) e\left[\sum_{k=1}^{n} a_{i j} \sum_{j=1}^{n} a_{k j}\right]^{-1}=\frac{1}{\sum_{k=1}^{n} u_{i j}}, \frac{1}{\sum_{k=1}^{n} m_{i j}}, \frac{1}{\sum_{k=1}^{n} l_{i j}}
$$

First, we calculate the matrix of the sum of the lines $\left(\sum_{j=1}^{n} a_{i j}\right)$ and then the vector of the sum of the columns of this matrix. Each $S_{i}$ was obtained by multiplying the matrix of the sum of the lines by the inverse of the vector of the sum of the columns.

Then, each $S_{i}$ obtained from Equation (3) was compared to the others to determine the possibility degree of $S_{i}$ being greater than or equal to $S_{j}$, that is, $V\left(S_{i} \geq S_{j}\right)$. This comparison was initially made two by two, by calculating $V\left(S_{i} \geq S_{j}\right)$, which represents the degree of possibility of $S_{i}$ being greater than or equal to $S_{j}$, using the Equation (4), where sup (supremum) represents the least upper bound of a set:

$$
V\left(S_{i} \geq S_{j}\right)=\sup _{Y \geq x}\left[\min \left(S_{j}(x), S_{i}(y)\right)\right]
$$

When we consider that $S i\left(l_{i}, m_{i}, u_{i}\right)$ and $S_{j}\left(l_{j}, m_{j}, u_{j}\right)$ are two convex triangular fuzzy numbers that intersect (Figure 6), we have:

$$
\begin{gathered}
V\left(S_{i} \geq S_{j}\right)=1 \text { se e somente se } m_{i}=j \text { e } \\
V\left(S_{j} \geq S_{i}\right)=\operatorname{Hgt}\left(S_{i} \cap S_{j}\right)=\left(l_{i}-u_{j}\right) /\left[\left(m_{j}-u_{j}\right)-\left(m_{i}-l_{i}\right)\right]=d
\end{gathered}
$$

Thus, Equation (4) can also be represented by:

$$
V\left(S_{j} \geq S_{i}\right)=\left\{\begin{array}{cc}
1 & m_{i} \geq m_{j} \\
\frac{l_{j}-u_{i}}{\left(m_{i}-u_{i}\right)-\left(m_{j}-l_{j}\right)} & l_{j} \geq u_{i} \\
0 & \text { otherwise }
\end{array}\right.
$$


The above principles were used to calculate the possibility degree that a fuzzy number $S_{i}$ for criterion $\mathrm{i}\left(C_{i}\right)$ is greater than all other convex fuzzy numbers of other criteria using the equation:

$$
d\left(C_{i}\right)=V\left(S_{i} \geq S_{a}, S_{b}, S_{c}, \ldots, S_{n}\right)=\operatorname{Min}\left(V\left(S_{i} \geq S_{a}\right), V\left(S_{i} \geq S_{b}\right), V\left(S_{i} \geq S_{c}\right), \ldots, V\left(S_{i} \geq S_{n}\right)\right)
$$

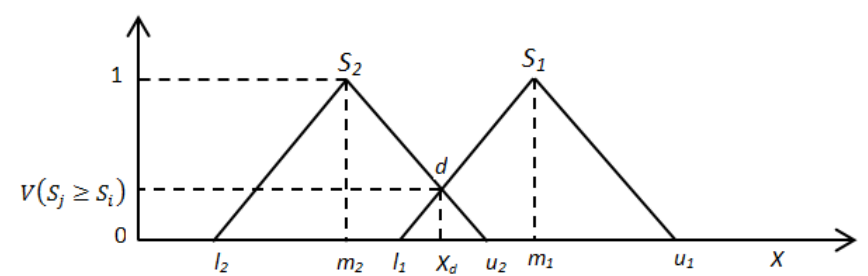

Figure 6. The comparison between two Fuzzy numbers.

As a result, we obtained the vector $W^{\prime}=\left[d\left(C_{a}\right), d\left(C_{b}\right), d\left(C_{c}\right), \ldots, d\left(C_{n}\right)\right]$, which, after normalizing using Equation (5), generated the vector $W$ of the criteria weights:

$$
W_{i}=\frac{V\left(S_{i} \geq S_{j} / j=1, \ldots, n ; j \neq i\right)}{\sum_{k=1}^{n} V\left(S_{k} \geq S_{j} / j=1, \ldots, n ; j \neq k\right)}, i=1, \ldots, n
$$

For the consistency analysis of the fuzzy pairwise comparison matrices, we use the Inconsistency Index [135], calculated from the following steps:

Step 1: Creation of two matrices: the first $\left(A_{m}\right)$ containing the middle numbers of the triangular fuzzy matrix, and the second $\left(A_{g}\right)$, containing the geometric mean of the upper and lower bounds of the triangular fuzzy matrix.

$$
\begin{gathered}
A_{m}=\left[a_{i j m}\right] \\
A_{g}=\left[\sqrt{a_{i j u} a_{i j l}}\right]
\end{gathered}
$$
$\lambda$ max.

Step 2: Calculation of weight vector based on the Saaty method and calculation of

Step 3: Calculation of the consistency index $\left(C_{i}\right)$ for $A_{m}$ and $A_{g}$ matrices:

$$
\begin{aligned}
& C I_{m}=\frac{\lambda_{\text {max }}^{m}-n}{n-1} \\
& C I_{g}=\frac{\lambda_{\text {max }}^{g}-n}{n-1}
\end{aligned}
$$

\begin{tabular}{|c|c|c|c|c|c|c|c|c|c|c|c|c|c|c|c|}
\hline$n$ & 1 & 2 & 3 & 4 & 5 & 6 & 7 & 8 & 9 & 10 & 11 & 12 & 13 & 14 & 15 \\
\hline $\mathrm{Ri}_{\mathrm{m}}$ & 0 & 0 & 0.489 & 0.794 & 1.072 & 1.200 & 1.287 & 1.341 & 1.379 & 1.410 & 1.418 & 1.446 & 1.456 & 1.491 & 1.499 \\
\hline $\mathrm{RI}_{\mathrm{q}}$ & 1 & 2 & 0.180 & 0.263 & 0.360 & 0.382 & 0.409 & 0.416 & 0.435 & 0.446 & 0.454 & 0.478 & 0.469 & 0.480 & 0.488 \\
\hline
\end{tabular}

Step 4: Calculation of the consistency ratio $(C R)$ of the matrices, dividing the consistency index $(C I)$ of each matrix by its random index $(R I)$ obtained from Table 5 . If the values of $C R_{m}$ and $C R_{g}$ are less than 0.1 , the matrices are consistent.

$$
\begin{gathered}
C R_{m}=\frac{C I_{m}}{R I_{m}} \\
C R_{g}=\frac{C I_{g}}{R I_{g}}
\end{gathered}
$$

Table 5. Random indices (RI) for consistency check. 


\subsubsection{Input Layers Aggregation}

In ArcGIS environment, we used the "Weighted Sum" tool that overlays several rasters, multiplying each raster of the criteria map by their given weight and summing them together to generate the overlay map. Then, we excluded the exclusion criteria (constraints) from this map to ensure that areas unsuitable for reforestation were excluded from the analysis to generate the final overlay map containing the same three classes of the criteria maps. Class 3 represents the best areas for reforestation.

\subsubsection{Evaluation of the Results' Robustness}

The weights obtained from the Fuzzy AHP may vary depending on the uncertainties of the judgment process, which makes it advisable to carry out a sensitivity analysis of the modeling based on the variation of parameters in a predefined interval [83]. In this sense, we used the One-At-a-Time (OAT) method [84] to investigate the sensitivities of the weights assigned to the maps, varying each separate influence and keeping the others unchanged. This approach of producing summary sensitivity indices for the study area is strongly recommended by the authors of Reference [85], even though it is known that the fuzzy method already considers the inaccuracies and ambiguities inherent in judgment processes based on human perception. Thus, for each map, we vary the weight by \pm 5 percent [73] using the following equation:

$$
\bar{p}_{i}=(1+t x) \times p_{j}
$$

where, $\bar{p}_{j}=$ weight of factor $j$ changed by the OAT method, $t x=$ rate of change of weight and $p_{j}=$ original weight.

However, for the sum of the weights to remain the same, the other weights were adjusted using the following equation:

$$
\bar{p}_{i}=p_{i} \times \frac{1-\bar{p}_{j}}{1-p_{j}}
$$

Then, we evaluated the methodology's effectiveness in identifying the best sites by comparing the best sites' characteristics with those expected, considering the authors' views of the articles that supported this work. In Section 2.4, we presented the characteristics of the factors that influence reforestation success from the authors' perspective who work with the theme. According to this approach, the best reforestation sites have a slope of less than $15 \%$, with eutrophic soil and vegetation that develops from species growth that naturally regenerates. Also, they must be close to forest fragments with low vulnerability.

\section{Results and Discussion}

Figure 7 shows the soil map. Soil is an important factor in planting and developing forest seedlings. The seedling survival rate is directly linked to the soil's physical and chemical characteristics $[87,88]$. The spatial pattern was classified into three classes. The first is represented by the eutrophic soil that occurs in $7 \%$ of the site. Eutrophic soils are characterized by having a low concentration of aluminum and chemical bases and have good fertility due to the availability of nutrients from the decomposition of organic matter. Thus, the eutrophic soil is the most suitable for planting forest seedlings [92]. The second class corresponds to the dystrophic soil with medium fertility and occurs in $85 \%$ of the study area. The third class refers to the acric soil, which occurs in $8 \%$ of the study area. This usually acidic soil has a high concentration of aluminum, hindering nutrient absorption by forest seedlings. Reforestation in areas with acric soil becomes expensive due to the need for intensive soil correction chemical treatments. 

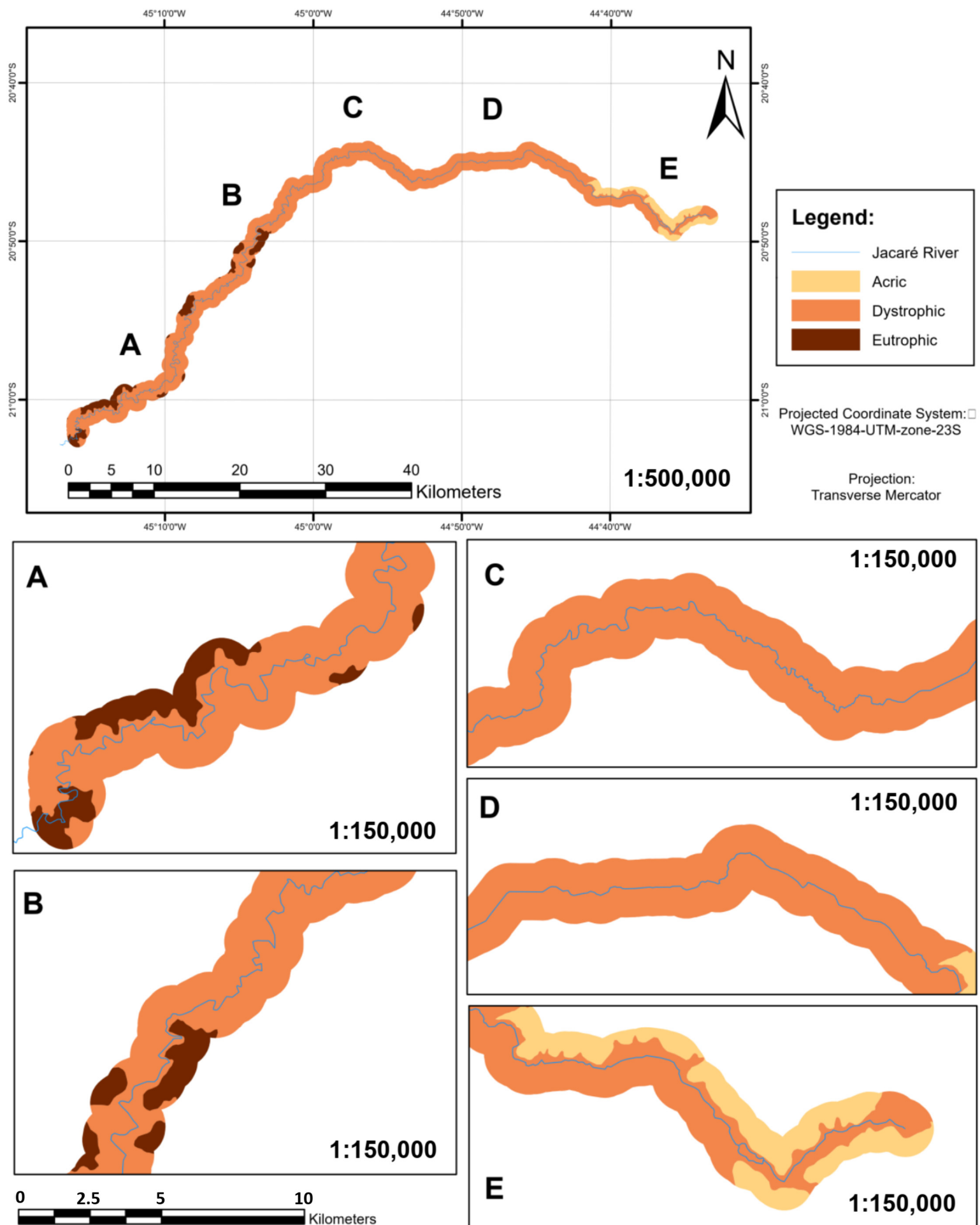

Figure 7. Soil map. (A-E) are the regions with the most significant potential for reforestation.

The lower portion of the river course has a matrix of dystrophic soil associated with patches of eutrophic soil. The proximity of these two classes of soil contributes to potentiate the success of planting in this region. The upper portion of the river presents continuous acric soil bands inserted in a dystrophic matrix, characterizing the region as not conducive to reforestation. The study area's central part shows only the occurrence of dystrophic soil and offers a medium contribution to reforestation.

Figure 8 shows the vegetation map. The vegetation cover of the reforestation site influences the establishment and growth of forest seedlings. The presence of vegetation 
in these areas conserves moisture, increases soil fertility and protects seedlings from the sun's radiation.
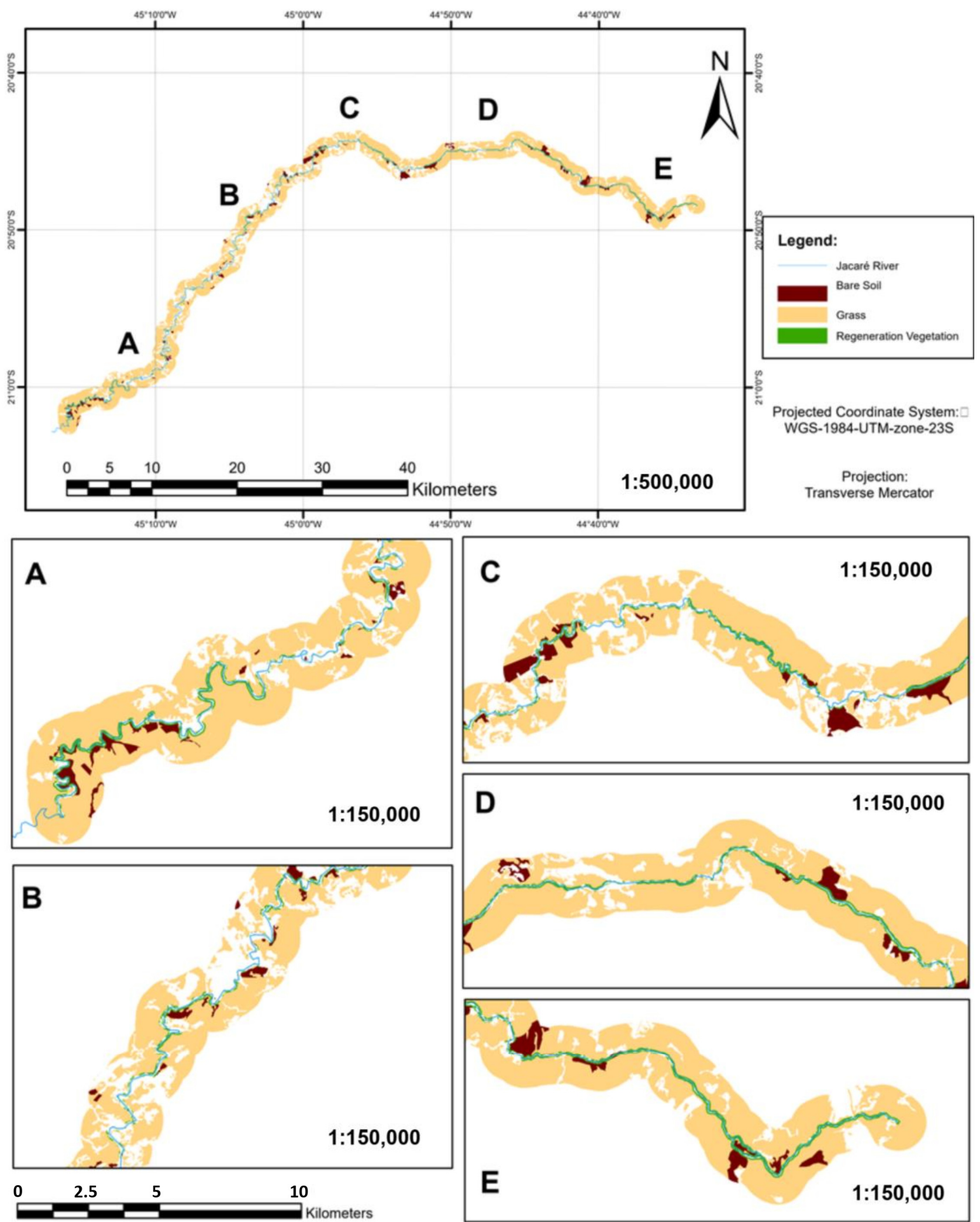

Figure 8. Vegetation map. (A-E) are the regions with the most significant potential for reforestation.

The spatial pattern was classified into three classes. The first class is composed of Capoeira or forest in the initial stage of regeneration, covering approximately $6 \%$ of the study area. These areas have semi-dense shrub vegetation originating from the natural regeneration of abandoned agricultural areas. This vegetation attributes moisture and fertility to the planting of forest seedlings and contributes to protecting seedlings against 
water loss $[93,94]$. The second class corresponds to pasture that occupies $90 \%$ of the total coverage. This type of vegetation is associated with extensive livestock activities. They are areas with herbaceous vegetation with a predominance of grasses and legumes with relative humidity and soil fertility. The third class, represented by bare soil, occupies $45 \%$ of the study area and has many mineral aggregates on its surface. They are devoid of vegetation and have little fertility and moisture. These areas suffer accelerated erosion and consequent loss of soil. These are areas not recommended for the reforestation process.

The spatial analysis of the distribution of vegetation cover classes in the study area shows that the regeneration vegetation is located next to the reforestation site, along the entire course of the Jacaré River, which enhances forest seedlings in these areas. The class represented by pastures is distributed both in the reforestation sites and in the adjacent regions over the watercourse's entire length. The bare soil class occurs mainly in patches located in the upper portion of the river. The presence of bare soil patches associated with pastures in the upper portion of the river makes this region less suitable for planting forest seedlings.

Figure 9 shows the slope map. The slope is directly associated with the water regime, fertility and soil stability. The lower the slope, the better the seed will germinate and fix the seedlings. Besides, lower slopes decrease the cost of planting and facilities management in the reforestation process.

The spatial pattern was classified into three slope classes. The first from $0 \%$ to $15 \%$ is characterized as having an important influence on reforestation and occupies $61 \%$ of the study area. The areas represented by the second class are between $15 \%$ and $30 \%$ of the slope, have little influence on the reforestation process and occupy $32 \%$ of the total study area. The third class has sites with a slope above $30 \%$ and occupy $7 \%$ of the entire study area.

The predominance of areas with low declivity occurs in the upper half of the river, especially close to the river sources and steep areas that are concentrated in the lower half of the watercourse.

Figure 10 shows the map of the distance from the forest fragment to the reforestation sites. The landscape pattern influences the ecological processes that guarantee the implantation and development of forest seedlings. Biological flows, such as the distance of seed dispersal and the wild animals' route, interfere with the dynamics of reforestation and contribute to the forest system sustainability to be implemented. In this way, the greater proximity of the forest fragment contributes to increased biological diversity at the reforestation site. This figure shows three buffers along the Jacaré River course, which identify contribution strips of forest fragments in the area adjacent to the reforestation site. The first, with $150 \mathrm{~m}$ from the riverbank, the second with $500 \mathrm{~m}$ and the third with $1000 \mathrm{~m}$. The most considerable contribution of forest fragments occurred in the lower half of the river course, where the largest forest fragments are located. The fact that they are grouped enhances their positive influence on the adjacent reforestation site.

Figure 11 shows the map of the vulnerability of adjacent forest fragment to the reforestation sites. The vulnerability degree of forest fragments determines structural, spatial and temporal patterns [115] that help identify the areas with the most significant potential for riparian reforestation [116]. The vulnerability of a forest fragment is directly associated with its total area. Thus, the size and quality of the sources of biodiversity in the fragment core decrease when the fragment area also decreases $[117,136]$. The reduction in the biological diversity of a forest fragment affects the colonization process' efficiency in adjacent areas. In this way, the less vulnerable a forest fragment is, the more significant its contribution to the reforestation success. 

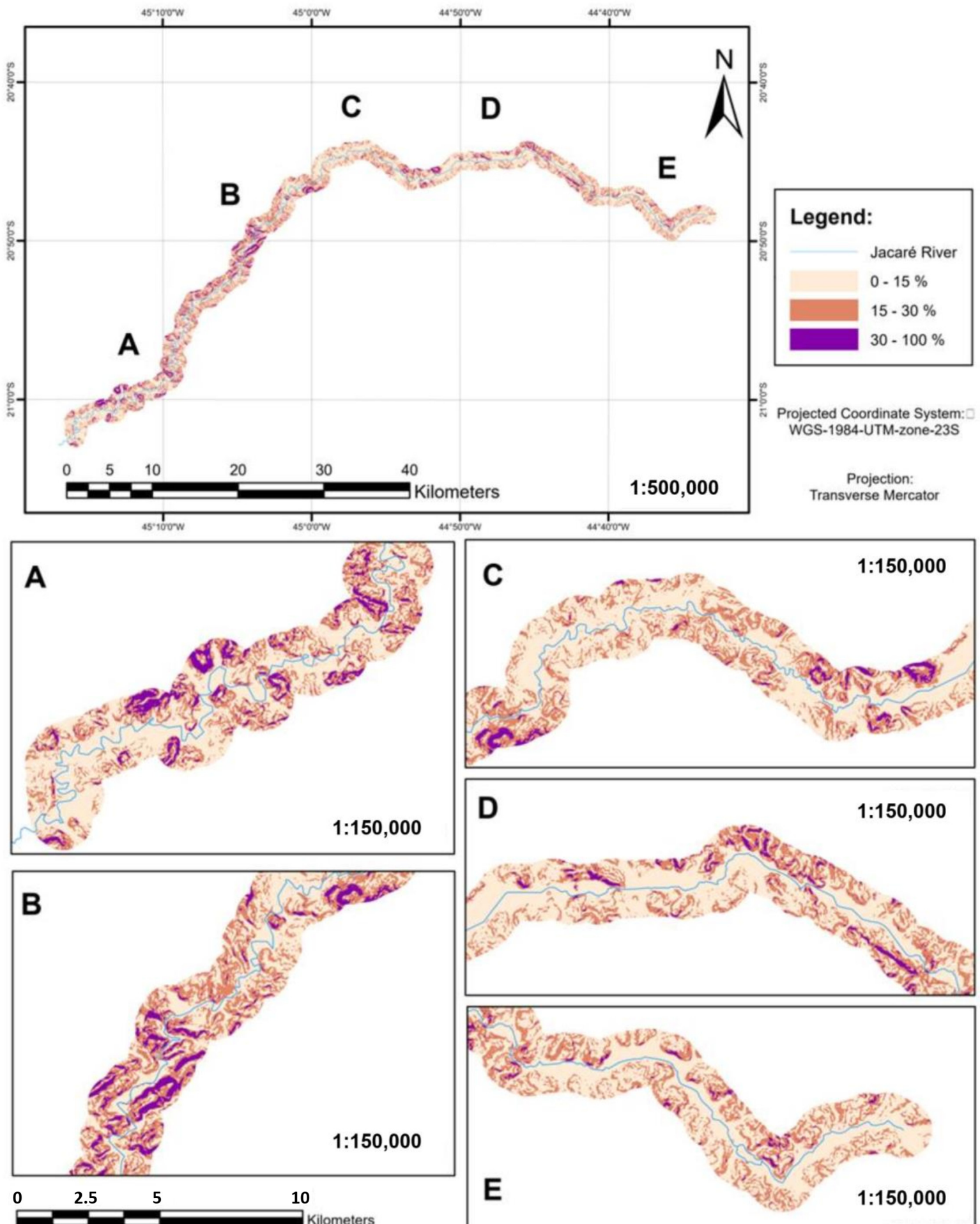

Figure 9. Slope map. (A-E) are the regions with the most significant potential for reforestation. 

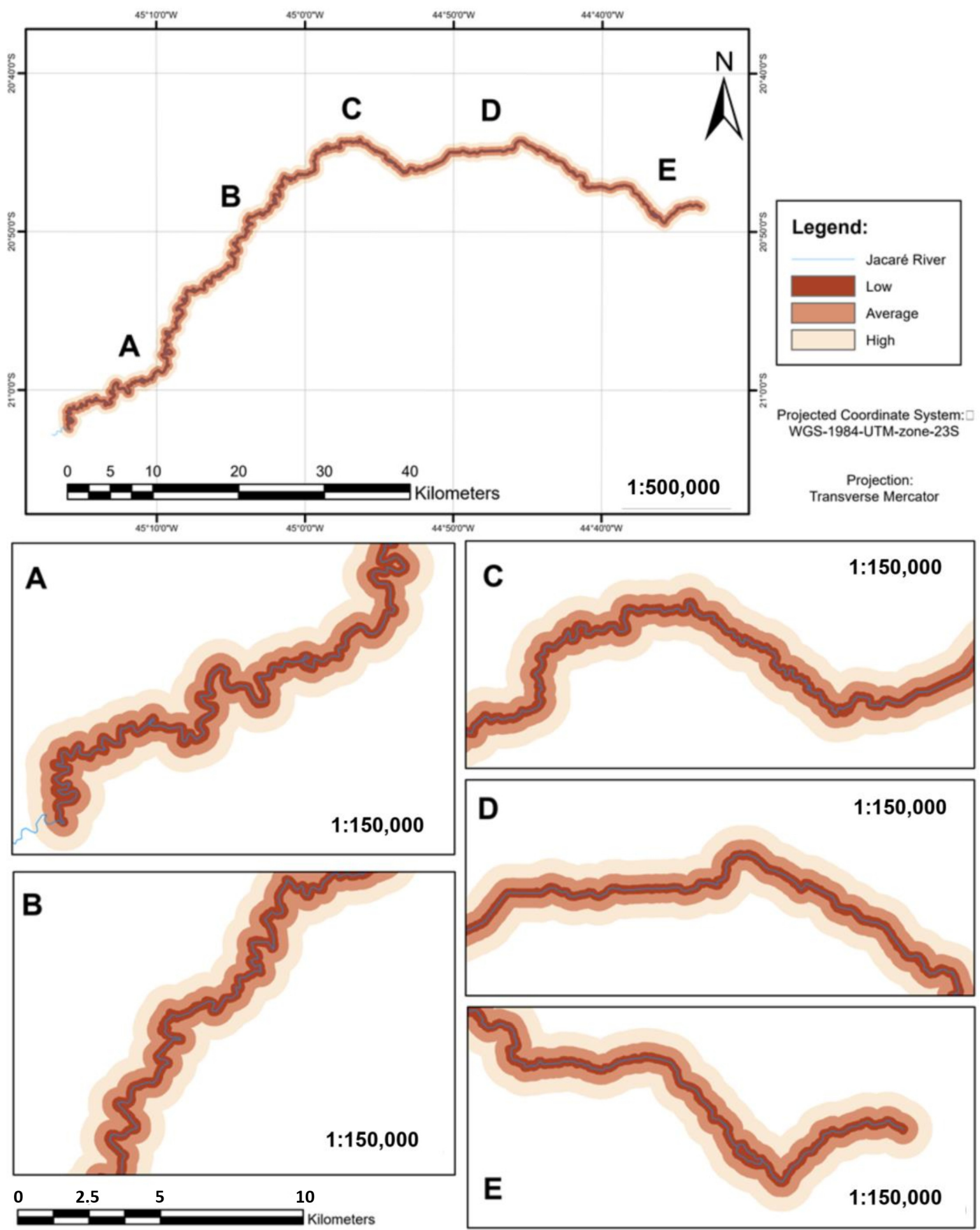

Figure 10. Map of the distance from the forest fragment to the reforestation sites. (A-E) are the regions with the most significant potential for reforestation. 

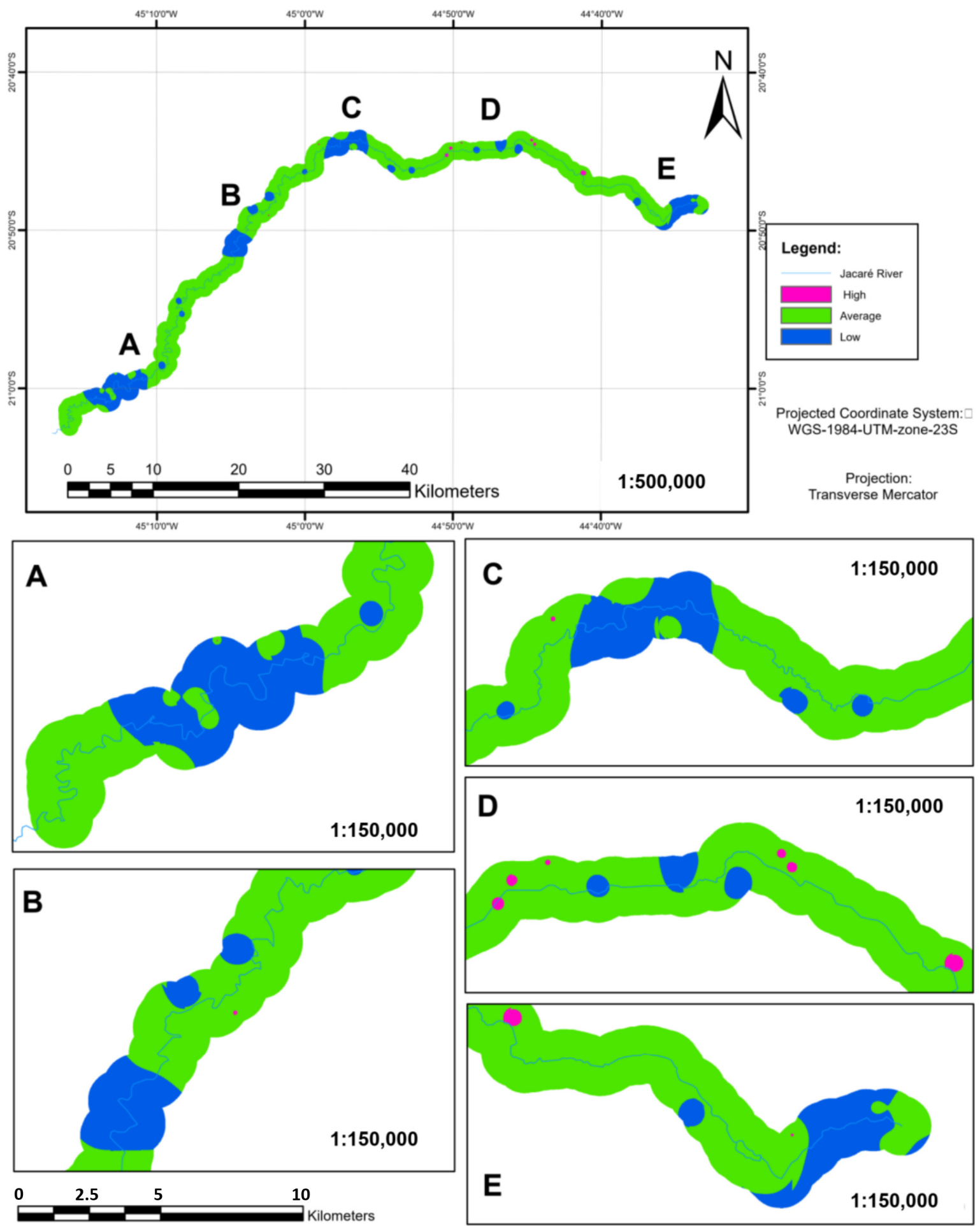

Figure 11. Map of the vulnerability of adjacent forest fragment to the reforestation sites. (A-E) are the regions with the most significant potential for reforestation.

Figure 11 shows three classes of influence of the vulnerability of forest fragments in the different reforestation sites. The first class is made up of areas with low vulnerability. These areas correspond to approximately $20 \%$ of the study area. These are areas that are influenced by the large extent of core area existing in adjacent fragments. The biodiversity in these fragments contributes to the reforestation site's colonization processes [104-106]. The second class presents areas with a moderate influence on the vulnerability of forest 
fragments. These areas correspond to $77 \%$ of the study area. The fragments that influence these areas have little core area, which contributes little to reforestation dynamics. The third class corresponds to the area of influence of forest fragments without a core area, which corresponds to $3 \%$ of the study area. These areas are not advisable for reforestation.

The spatial configuration of the study area presents five concentrations of the site with little vulnerability. These areas are distributed over the entire course of the river and are recommended for planting forest seedlings. The areas of moderate influence of the vulnerability of the adjacent fragments are distributed throughout the study area. The areas influenced by fragments with high vulnerability are scarce and located in the river's upper portion.

Figure 12 shows the constraints map. Areas of forests, rocky outcrops, urban centers, highways, railways and areas with a slope equal to or greater than $45^{\circ}$, are strong limitations to the success of riparian reforestation. Thus, these areas unsuitable for reforestation were removed from the analysis.
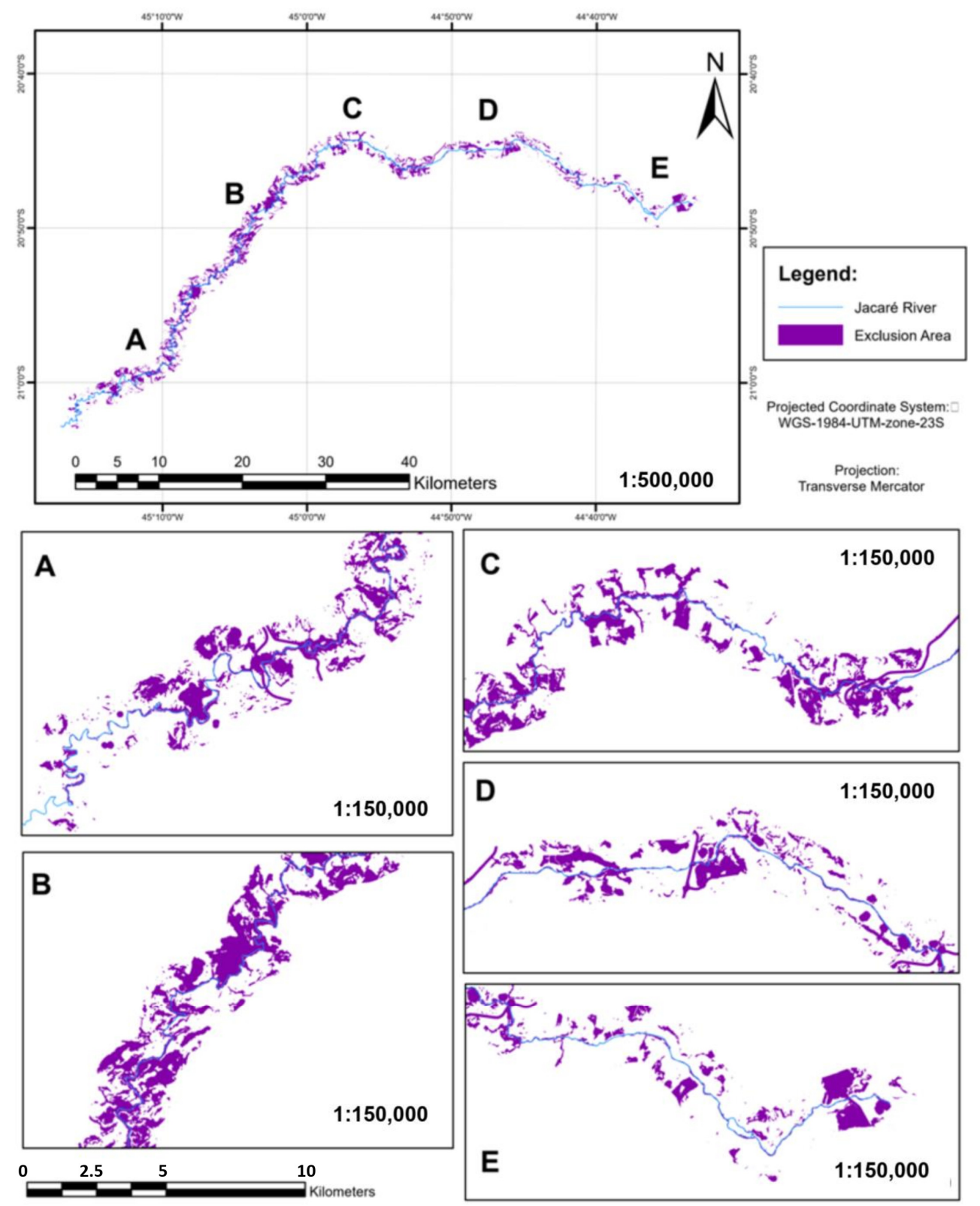

Figure 12. Constraints map. (A-E) are the regions with the most significant potential for reforestation. 
Exclusion areas are concentrated in the lower portion of the Jacaré River. The multiple presences of urban nuclei in the lower course of the river exerts high anthropic pressure in the adjacent areas. These areas suffer from domestic animals' presence, fire risk and the very disordered urban fabric expansion.

These anthropic pressure agents directly interfere in the development of the riparian forest. In the lower course of the river, we find extensive areas with a slope equal to or greater than $45^{\circ}$. Due to the rain regime in the region, these areas have a strong erosive activity, which causes loss of soil and nutrients and is difficult to access for planting. Thus, these areas become less suitable for reforestation.

Figure 13 shows the overlay map's spatial pattern classified into three classes according to the potential for riparian reforestation.
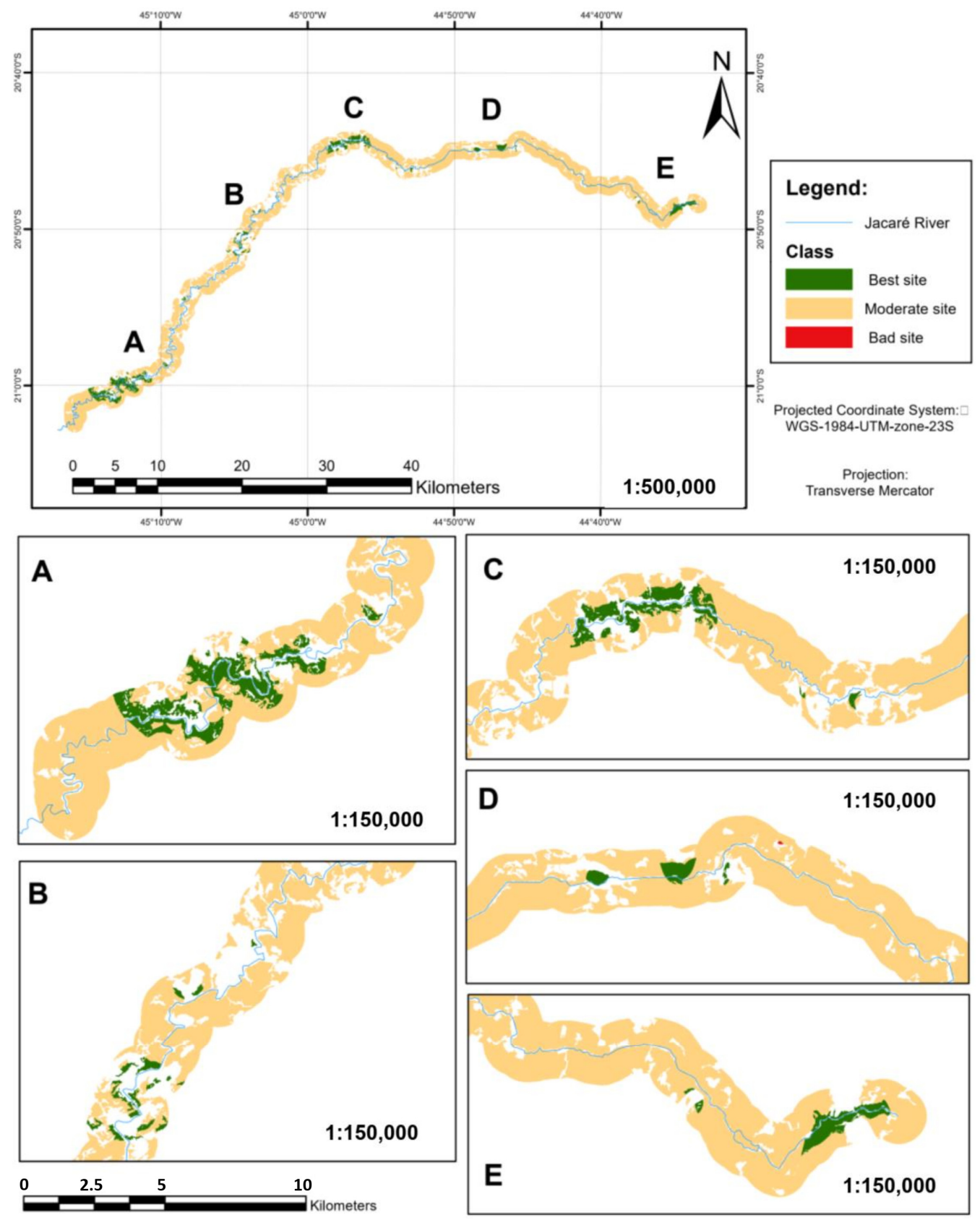

Figure 13. Priority area for reforestation in Jacaré River extension. (A-E) show the priority areas for reforestation. 
The areas that prevail are those with moderate reforestation chances, representing $69 \%$ of the study area. Most of these areas are covered by pasture, which offers a reasonable contribution to forest seedlings' growth compared to areas without vegetation. However, as they contain less tree density, they are more exposed to solar radiation, contributing to water stress and increasing the need for irrigation of planted seedlings. Its composition and structure also facilitate the spread of fire in vegetation. The sites with the least potential for reforestation represent $1 \%$ of the study area.

The best sites represent $7 \%$ of the study area and are concentrated in five regions, whose spatial arrangement enhances physical, chemical and biological interactions. They create environments that favor the development of aquatic and riverside life and the maintenance of ecological balance, thus bringing together fundamental characteristics for water resources' sustainability.

The overlay map showed that the vulnerability map of adjacent forest fragments most influenced the overlay map's spatial pattern. It is because, in the five layers of entry, the places that moderately contribute to the success of reforestation (Class 2) prevailed, and because the overlap of the places that most contribute to the reforestation success (Class 3) was more significant among the vulnerabilities map of adjacent forest fragments and other maps.

Regarding the robustness of the modeling, some aspects stand out. Regarding the identification of the factors used to build the input layers, we adopted two premises. The first was to identify the main factors that influence the success of reforestation from broad and detailed bibliographic research through systematic review, while the second is that the data regarding the factors could be easily obtained

Regarding the consistency of the fuzzy pairwise comparison matrices, the consistency indices $C R_{m}$ and $C R_{g}$ were less than 0.1 , which proved the consistency

Regarding the sensitivity of the weights assigned to the maps, Table 6 shows that small changes in the three classes proved that the maps' weights' variation had a little impact on the number of sites, increasing confidence in the methodology used in this work.

Table 6. Sensitivity analysis.

\begin{tabular}{|c|c|c|c|c|}
\hline \multirow{2}{*}{ Layer Name } & \multirow{2}{*}{ Weight Variation } & \multicolumn{3}{|c|}{ Number of Classes } \\
\hline & & 1 & 2 & 3 \\
\hline Number of Overlay Classes & & 1 & 117 & 60 \\
\hline \multirow{2}{*}{ Slope } & $+5 \%$ & 1 & 118 & 61 \\
\hline & $-5 \%$ & 1 & 118 & 60 \\
\hline \multirow{2}{*}{ Soil } & $+5 \%$ & 1 & 118 & 61 \\
\hline & $-5 \%$ & 1 & 118 & 60 \\
\hline \multirow{2}{*}{ Vegetation } & $+5 \%$ & 1 & 118 & 60 \\
\hline & $-5 \%$ & 1 & 118 & 60 \\
\hline \multirow{2}{*}{ Vulnerability of adjacent forest fragments to the reforestation sites } & $+5 \%$ & 1 & 118 & 65 \\
\hline & $-5 \%$ & 1 & 120 & 61 \\
\hline \multirow{2}{*}{ Distance from the forest fragment to the reforestation sites } & $+5 \%$ & 1 & 118 & 60 \\
\hline & $-5 \%$ & 1 & 118 & 61 \\
\hline
\end{tabular}

Regarding the effectiveness of modeling to identify the best sites with characteristics compatible with the literature on the topic, the best sites have mainly eutrophic soil, with a slope of up to $15 \%$. Besides, they are mostly covered by grasses and are close to forest fragments of low vulnerability. This result is compatible with the authors' view of the articles that supported this work. According to these authors, eutrophic soil is fertile, enhancing plant growth [92]. 
Regarding the slope, it is directly associated with changes in physical and chemical properties of the land [98]. Thus, smaller slopes favor stability, fertility and water regime of the soil. It enhances small sites' appearance that assists in the fixation and growth of forest seedlings and seed germination in the colonization processes [87,95-97]. Restoration studies in tropical forests have observed faster growth of forest seedlings on less steep slopes in addition to high seedling mortality on steeper slopes [97], and highlight that riverside vegetation is strongly influenced by the longitudinal and lateral connectivity of the surface of the floodplain. These areas contribute to the increase of microbiological activity and consequent soil fertility and the transport and dispersion of seeds.

Concerning the proximity to forest fragments of low vulnerability, in fragmented landscapes, forest fragments provide refuge for many forest species and seeds that enhance reforestation [92-94]. They work as stepping-stones that increase pollinators' and dispersers' visits and promote colonization by alien species. The proximity of these fragments to the reforestation sites also facilitates colonization of these areas by local species [104-106].

These results show the robustness of the modeling to identify the best areas for riparian forest reforestation.

\section{Conclusions}

In a context in which anthropic impacts and climate change effects negatively influence the quality and quantity of water resources, and the riparian forest fragmentation undermines its ability to mitigate the consequences of these adverse effects, in this work, we used a methodology that integrates GIS, fuzzy logic, AHP and sensitivity analysis to model the selection of FMP stretches that present the best conditions for riparian forest successful reforestation, using a real case, the Jacaré river basin, whose characteristics are frequently found in Brazilian watersheds.

This work presented the typical limitation of studies that use bibliographic research to support their analysis. Although we have carried out extensive and detailed bibliographic research, there is always a risk that a relevant article has not been included. It also has the limitation of subjectivity resulting from the expert's interpretation about what is being evaluated. However, the AHP, OAT and fuzzy set theory methods reduced the possibility that inaccuracies and ambiguities could influence the results. Another limitation concerns the use of GIS. Although it is an essential tool for the representation and analysis of spatial patterns, it demands professionals who are not always part of small-town governments' teams.

Considering the scarcity of resources experienced by many countries, we hope that the results of this work can collaborate so that governments can prioritize their efforts.

Author Contributions: Conceptualization, survey, data curation, methodology, writing—original draft, formal analysis, writing - review and editing, D.H.A.T., D.d.C.V.N. and C.A.P.S.; data curation, visualization, writing - review and editing, D.V.M.d.S.; supervision, C.A.P.S. All authors have read and agreed to the published version of the manuscript.

Funding: This research received no external funding.

Data Availability Statement: The data presented in this study are available in this article.

Acknowledgments: The authors would like to thank all the experts who answered the survey. The authors also express their gratitude to the editor and anonymous reviewers for comments and suggestions.

Conflicts of Interest: The authors declare no conflict of interest.

\section{References}

1. Zhang, L.; Hickel, K.; Shao, Q. Predicting Afforestation Impacts on Monthly Streamflow Using the Dwbm Model. Ecohydrology 2017, 10, e1821. [CrossRef]

2. Gashaw, T.; Tulu, T.; Argaw, M.; Worqlul, A.W. Modeling the Hydrological Impacts of Land Use/Land Cover Changes in the Andassa Watershed, Blue Nile Basin, Ethiopia. Sci. Total. Environ. 2018, 619, 1394-1408. [CrossRef] [PubMed] 
3. Dugdale, S.J.; Malcolm, I.A.; Kantola, K.; Hannah, D.M. Stream Temperature under Contrasting Riparian Forest Cover: Understanding Thermal Dynamics and Heat Ex-change Processes. Sci. Total. Environ. 2018, 610-611, 1375-1389. [CrossRef] [PubMed]

4. Metzger, J.P. O Que é ecologia de Paisagens? Biota Neotrop. Camp. 2001, 1, 1-9. [CrossRef]

5. Vital, A.R.T.; Guerrini, I.A.; Franken, W.K.; Fonesca, R.C.B. Produção de Serapilheira e Ciclagem de Nutrientes de uma Floresta Estacional Semidecidual em Zona Ripária. Rev. Árvore 2004, 28, 793-800. [CrossRef]

6. Lacerda, A.V.; Nordi, N.; Barbosa, F.M.; Watanabe, T. Levantamento Florístico Do Componente Arbustivo-Arbóreo Da Vegetação Ciliar NA Bacia Do Rio Taperoá, PB, Brasil. Acta Bot. Bras. 2005, 19, 647-656. [CrossRef]

7. Attanasio, C.M.; Lima, W.P.; Gandolfi, S.; Zakia, J.M.B.; Veniziani, J.; Toledo, J.C. Método para a Adentificação da Zona Ripária: Microbacia Hidrográfica do Ribeirão São João (Mineiros do Tietê, SP). Sci. For. 2006, 71, 131-140.

8. Chetkiewicz, C.-L.B.; Clair, C.C.S.; Boyce, M.S. Corridors for Conservation: Integrating Pattern and Process. Annu. Rev. Ecol. Evol. Syst. 2006, 37, 317-342. [CrossRef]

9. Giehl, E.L.H.; Jarenkow, J.A. Gradiente Estrutural No Componente Arbóreo e Relação com Inundações em uma Floresta Ribeirinha, Rio Uruguai, Sul Do Brasil. Acta Bot. Bras. 2008, 22, 741-753. [CrossRef]

10. Caissie, D. The Thermal Regime of Rivers: A Review. Freshw. Biol. 2006, 51, 1389-1406. [CrossRef]

11. Marmontel, C.V.F.; Rodrigues, A.V. Indicative Parameters for Water Quality in Water Springs with Different Land Cover and Conservation of Riparian Vegetation. Floresta Ambiente 2015, 22, 171-181. [CrossRef]

12. Tufekcioglu, A.; Raich, J.; Isenhart, T.; Schultz, R. Soil Respiration within Riparian Buffers and Adjacent Crop Fields. Plant Soil 2001, 229, 117-124. [CrossRef]

13. Benyahya, L.; Caissie, D.; Satish, M.G.; El-Jabi, N. Long-Wave Radiation and Heat Flux Estimates within a Small Tributary in Catamaran Brook (New Brunswick, Canada). Hydrol. Process. 2012, 26, 475-484. [CrossRef]

14. Dugdale, S.J.; Bergeron, N.E.; St-Hilaire, A. Spatial Distribution of Thermal Refuges Analysed in Relation to Riverscape Hydromorphology Using Airborne Thermal Infrared Imagery. Remote. Sens. Environ. 2015, 160, 43-55. [CrossRef]

15. Garner, G.; Malcolm, I.A.; Sadler, J.P.; Hannah, D.M. What Causes Cooling Water Temperature Gradients in a Forested Stream Reach? Hydrol. Earth Syst. Sci. 2014, 18, 5361-5376. [CrossRef]

16. Leach, J.A.; Moore, R.D. Above-Stream Microclimate and Stream Surface Energy Exchanges in a Wildfire-Disturbed Riparian Zone. Hydrol. Process. 2010, 24, 2369-2381. [CrossRef]

17. Breau, C.; Cunjak, R.A.; Peake, S.J. Behaviour during Elevated Water Temperatures: Can Physiology Explain Movement of Juvenile Atlantic Salmon to Cool Water? J. Anim. Ecol. 2011, 80, 844-853. [CrossRef]

18. Dugdale, S.J.; Franssen, J.; Corey, E.; Bergeron, N.E.; Lapointe, M.; Cunjak, R.A. Main Stem Movement of Atlantic Salmon Parr in Response to High River Temperature. Ecol. Freshw. Fish 2015, 25, 429-445. [CrossRef]

19. Martins, E.G.; Hinch, S.G.; Patterson, A.D.; Hague, M.J.; Cooke, S.J.; Miller, K.M.; Robichaud, D.; English, K.K.; Farrell, A.P. High River Temperature Reduces Survival of Sockeye Salmon (Oncorhynchus Nerka) Approaching Spawning Grounds and Exacerbates Female Mortality. Can. J. Fish. Aquat. Sci. 2012, 69, 330-342. [CrossRef]

20. Ilstedt, U.; Malmer, A.; Verbeeten, E.; Murdiyarso, D. The Effect of Afforestation on Water Infiltration in the Tropics: A Systematic Review and Meta-Analysis. For. Ecol. Manag. 2007, 251, 45-51. [CrossRef]

21. Olaf, B.; Stefan, S.; Nico, E. Interactive Effects of Warming, Soil Humidity and Plant Diversity on Litter Decomposition and Microbial Activity. Soil Biol. Biochem. 2011, 43, 1902. [CrossRef]

22. Godsey, S.; Elsenbeer, H. The Soil Hydrologic Response to Forest Regrowth: A Case Study from Southwestern Amazonia. Hydrol. Process. 2002, 16, 1519-1522. [CrossRef]

23. Brauman, K.A.; Freyberg, D.L.; Daily, G.C. Potential Evapotranspiration from Forest and Pasture in the Tropics: A Case Study in Kona, Hawai'i. J. Hydrol. 2012, 440-441, 52-61. [CrossRef]

24. Brummelhaus, J.; Weber, J.; Petry, M.V. The Influence of Riparian Forest Fragmentation on Birds in the River Hydro-Graphic Basin, Rio Grande do Sul State. Neotrop. Biol. Conserv. 2012, 7, 57-66.

25. Kuntschik, D.P.; Eduarte, M.; Uehara, T. Matas Ciliares; Coordenadoria de Biodiversidade e Recursos Naturais Secretaria do Meio Ambiente: São Paulo, Brazil, 2014; Volume 2, pp. 80-86.

26. Puth, L.; Wilson, K.A. Boundaries and Corridors: A Review of Streams and Their Role in the Landscape. Conserv. Biol. 2001, 15, 21-30. [CrossRef]

27. Rodrigues, R.R.; Leitão Filho, H.F. Matas Ciliares, Conservação e Recuperação, 2nd ed.; Edusp: São Paulo, Brazil, $2001 ;$ p. 320.

28. Carvalho, D.A.; Filho, A.O.; Vilela, E.A.; Curi, N.; Berg, E.V.D.; Fontes, M.; Botezelli, L. Distribuição de Espécies ArbóreoArbustivas ao Longo de um Gradiente de Solos e Topografia em um Trecho de Floresta Ripária Do Rio São Francisco em Três Marias, MG. Rev. Bras. Bot. 2005, 28, 2-345. [CrossRef]

29. Dudgeon, D.; Angela, H.; Arthington, M.O.; Kawabata, G.Z.; Duncan, J.; Knowler, D.J.; Lévêque, C.; Naiman, R.J.; Prieur-Richard, A.; Soto, D.; et al. Freshwater Biodiversity: Importance, Threats, Status and Conservation Challenges. Biol. Rev. 2006, 81, 163-182. [CrossRef]

30. Wantzen, K.M.; Mol, J.H. Soil Erosion from Agriculture and Mining: A Threat to Tropical Stream Ecosystems. Agriculture 2013, 3, 660-683. [CrossRef]

31. Boulton, A.J.; Fenwick, G.D.; Hancock, P.J.; Harvey, M.S. Biodiversity, Functional Roles and Ecosystem Services of Groundwater Invertebrates. Invertebr. Syst. 2008, 22, 103-116. [CrossRef] 
32. Alexander, R.B.; Elizabeth, W.; Boyer Richard, A.; Smith, G.; Schwarz, R.E.; Moore, B. The Role of Headwater Streams in Downstream Water Quality. JAWRA 2007, 43, 41-59.

33. Covich, A.P. Protecting Benthic Biodiversity to Insure Organic Matter Processing and Ecosystem Services: Importance of in-Vertebrate Shredders in Stream Networks. Ecotropicos 2006, 19, 109-127. [CrossRef]

34. Lorion, C.M.; Kennedy, B.P. Relationships between Deforestation, Riparian Forest Buffers and Benthic Macroinvertebrates in Neotropical Headwater Streams. Freshw. Biol. 2008, 54, 165-180. [CrossRef]

35. Villela, S.M.; Mattos, A. Hidrologia Aplicada; McGraw-Hill: São Paulo, Brazil, 1975; pp. 223-239.

36. García-Ruiz, J.M.; Lana-Renault, N. Hydrological and Erosive Consequences of Farmland Abandonment in Europe, with Special Reference to the Mediterranean Region-A Review. Agric. Ecosyst. Environ. 2011, 140, 317-338. [CrossRef]

37. Wiekenkamp, I.; Huisman, J.; Bogena, H.; Graf, A.; Lin, H.; Drüe, C.; Vereecken, H. Changes in Measured Spatiotemporal Patterns of Hydrological Response after Partial Deforestation in a Head-Water Catchment. J. Hydrol. 2016, 542, 648-661. [CrossRef]

38. Armanini, A.; Righetti, M.; Grisenti, P. Direct Measurement of Vegetation Resistance in Prototype Scale. J. Hydraul. Res. 2005, 43, 481-487. [CrossRef]

39. Li, J.-F.; Tfwala, S.; Chen, S.-C. Effects of Vegetation Density and Arrangement on Sediment Budget in a Sediment-Laden Flow. Water 2018, 10, 1412. [CrossRef]

40. Wang, J.; Ning, S.; Khujanazarov, T. Modeling Hydrological Appraisal of Potential Land Cover Change and Vegeta-tion Dynamics under Environmental Changes in a Forest Basin. Forests 2018, 9, 451. [CrossRef]

41. Bowmer, K.H. Ecosystem Effects from Nutrient and Pesticide Pollutants: Catchment Care as a Solution. Resources 2013, 2, 439-456. [CrossRef]

42. Perkins, K.S.; Nimmo, J.R.; Medeiros, A.C.; Szutu, D.J.; von Allmen, E. Assessing Effects of Native Forest Restoration on Soil Moisture Dynamics and Potential Aquifer Recharge, Auwahi, Maui. Ecohydrology 2014, 54, 126-142. [CrossRef]

43. Mrozińska, N.; Glińska-Lewczuk, K.; Burandt, P.; Kobus, S.; Gotkiewicz, W.; Szymańska, M.; Bąkowska, M.; Obolewski, K. Water Quality as an Indicator of Stream Restoration Effects-A Case Study of the Kwacza River Restoration Project. Water 2018, 10, 1249. [CrossRef]

44. Braga, R.A.P. Avaliação dos instrumentos de Políticas Públicas na Conservação Integrada de Florestas e Águas, com Estudo de Caso na Bacia do Corumbataí-SP. Ph.D. Thesis, Escola de Engenharia de São Carlos, Universidade de São Paulo, São Carlos, Brazil, 2005.

45. Ficke, A.D.; Myrick, C.A.; Hansen, L.J. Potential Impacts of Global Climate Change on Freshwater Fisheries. Rev. Fish Biol. Fish. 2007, 17, 581-613. [CrossRef]

46. Morrill, J.C.; Bales, R.C.; Conklin, M.H. Estimating Stream Temperature from Air Temperature: Implications for Future Water Quality. J. Environ. Eng. 2005, 131, 139-146. [CrossRef]

47. Van Vliet, M.T.; Franssen, W.H.; Yearsley, J.R.; Ludwig, F.; Haddeland, I.; Lettenmaier, D.P.; Kabat, P. Global River Discharge and Water Temperature under Climate Change. Glob. Environ. Chang. 2013, 23, 450-464. [CrossRef]

48. Boyero, L.; Ramírez, A.; Dudgeon, D.; Pearson, R.G. Are Tropical Streams Really Different? J. N. Am. Benthol. Soc. 2009, 28, 397-403. [CrossRef]

49. Güecker, B.; Boëchat, I.G.; Giani, A. Impacts of Agricultural Land Use on Ecosystem Structure and Whole-Stream Metabolism of Tropical Cerrado Streams. Freshw. Biol. 2009, 54, 2069-2085. [CrossRef]

50. Silva Junior, C.H.L.; Aragão, L.E.O.C.; Fonseca, M.G.; Almeida, C.T.; Vedovato, L.B.; Anderson, L.O. Deforestation-Induced Fragmentation Increases Forest Fire Occurrence in Central Brazilian Amazonia. Forests. 2018, 9, 305. [CrossRef]

51. Primack, R.B.; Rodrigues, E. Biologia da Conservação; Editora Planta: Londrina, Brazil, 2013; pp. 69-113.

52. Gonzaga, L.A.P. Conservação e Atração das Aves; Fundação Brasileira para a Conservação da Natureza: Rio de Janeiro, Brazil, 1984; p. 54.

53. Terborgh, J. Maintenance of Diversity in Tropical Forests. Biotropica 1992, 24, 283. [CrossRef]

54. Goerck, J.M. Patterns of Rarity in the Birds of the Atlantic Forest of Brazil. Patrones de Rareza en las Aves del Bosque Atlantico de Brasil. Conserv. Biol. 1997, 11, 112-118. [CrossRef]

55. Fontana, C.S.; Bencke, G.A.; Reis, R.E. Livro Vermelho da Fauna Ameaçada de Extinção no Rio Grande do Sul; EDIPUCRS: Porto Alegre, Brazil, 2003; p. 632.

56. Gimenes, M.R.; Anjos, L. Efeitos da Fragmentação Florestal Sobre Comunidades de Aves. Acta Sci. Biol. Sci. 2003, 2, 391-402. [CrossRef]

57. Laps, R.R.; Cordeiro, P.H.C.; Kajiwara, D.; Ribon, R.; Rodrigues, A.A.F.; Uejima, A. As Aves. In Fragmentação de Ecossistemas: Causas, Efeitos Sobre a Biodiversidade e Recomendações de Políticas Públicas; MMA/SBF: Brasília, Brazil, 2003; pp. 153-158.

58. Chan, E.K.W.; Yu, Y.-T.; Zhang, Y.; Dudgeon, D. Distribution Patterns of Birds and Insect Prey in a Tropical Riparian Forest. Biotropica 2008, 40, 623-629. [CrossRef]

59. Malczewski, J. GIS and Multicriteria Decision Analysis; John Wiley: New York, NY, USA, 1999; pp. $283-294$.

60. Chen, J. GIS-Based Multi-Criteria Analysis for Land use Suitability Assessment in City of Regina. Environ. Syst. Res. 2014, 3, 13. [CrossRef]

61. Akbulak, C. Land use Suitability Analysis of the Upper Basin of the Kara Menderes River using Analytical Hierarchy Process and Geographicalinformation Systems. Int. J. Hum. Sci. 2010, 7, 557-576. 
62. Malczewski, J. GIS-Based Multicriteria Decision Analysis: A Survey of the Literature. Int. J. Geogr. Inf. Sci. 2006, 20, 703-726. [CrossRef]

63. Phua, M.-H.; Minowa, M. A GIS-Based Multi-Criteria Decision Making Approach to Forest Conservation Planning at a Landscape Scale: A Case Study in the Kinabalu Area, Sabah, Malaysia. Landsc. Urban Plan. 2005, 71, 207-222. [CrossRef]

64. Valente, R.O.A.; Vettorazzi, C.A. Comparação entre Métodos de Avaliação Multicriterial, em Ambiente SIG, para a Conservação e a Preservação Florestal. Sci. For. 2005, 69, 51-61.

65. Jansssen, R.; Rietveld, P. Multicriteria Analysis and GIS: An Application to Agricultural Landuse in the Netherlands. In Geographical Lnformation Systems for Urban 'and Regional Planning; Kluwer: Dordrecht, The Netherlands, $1990 ;$ pp. 57-68.

66. Kainz, W. Fuzzy Logic and GIS. Vienna: University of Vienna. Available online: http://homepage.univie.ac.at/wolfgang.kainz/ Lehrveranstaltungen/ESRI_Fuzzy_Logic/File_2_Kainz_Text.pdf (accessed on 14 May 2020).

67. Yanar, T.A.; Akyurek, Z. The Enhancement of the Cell-Based GIS Analysis with Fuzzy Processing Capabilities. Inf. Sci. 2006, 176, 1067-1085. [CrossRef]

68. Robinson, V.B. A Perspective on the Fundamentals of Fuzzy Sets and Their Use in Geographic Information Systems. Trans. GIS 2003, 7, 3-30. [CrossRef]

69. Saaty, T. The Analytic Hierarchy Process; McGraw-Hill: New York, NY, USA, 1980.

70. Carver, S.J. Integrating Multi-Criteria Evaluation with Geographical Information Systems. Int. J. Geogr. Inf. Syst. 1991, 5, 321-339. [CrossRef]

71. Malczewski, J. GIS-Based Land-Use Suitability Analysis: A Critical Overview. Prog. Plan. 2004, 62, 3-65. [CrossRef]

72. Tang, Y.; Beynon, M.J. Application and Development of a Fuzzy Analytic Hierarchy Process within a Capital Investment Study. J. Econ. Manag. 2005, 1, 2, 207-230.

73. Tsiko, R.G.; Haile, T.S. Integrating Geographical Information Systems, Fuzzy Logic and Analytical Hierarchy Process in Modelling Optimum Sites for Locating Water Reservoirs. A Case Study of the Debub District in Eritrea. Water 2011, 3, 254-290. [CrossRef]

74. Arefiev, N.; Terleev, V.; Badenko, V. GIS-Based Fuzzy Method for Urban Planning. Procedia Eng. 2015, 117, 39-44. [CrossRef]

75. Lyu, H.-M.; Shen, S.-L.; Zhou, A.; Zhou, W.-H. Flood Risk Assessment of Metro Systems in a Subsiding Environment Using the Interval FAHP-FCA Approach. Sustain. Cities Soc. 2019, 50, 101682. [CrossRef]

76. Kayastha, P.; Bijukchhen, S.M.; Dhital, M.R.; De Smedt, F. GIS Based Landslide Susceptibility Mapping Using a Fuzzy Logic Approach: A Case Study from Ghurmi-Dhad Khola Area, Eastern Nepal. J. Geol. Soc. India 2013, 82, 249-261. [CrossRef]

77. Lin, W.-T.; Tsai, J.-S.; Lin, C.-Y.; Huang, P.-H. Assessing Reforestation Placement and Benefit for Erosion Control: A Case Study on the Chi-Jia-Wan Stream, Taiwan. Ecol. Model. 2008, 211, 444-452. [CrossRef]

78. Niknejad, M.; Fallah, A.; Limaei, S.M. Sustainable Development of Reforestation Using Goal Programing and Fuzzy—AHP. Iran. J. For. Poplar Res. 2018, 26, 252-263. [CrossRef]

79. Hassan, A.G.; Bakhtiar, F.; Thomas, B. GIS- Based Forest Fire Risk Mapping Using the Analytical Network Pro-cess and Fuzzy Logic. J. Environ. Plan. Manag. 2020, 63, 481-499. [CrossRef]

80. Zadeh, L.A. Fussy Sets. Inform. Contr. 1965, 8, 338-353. [CrossRef]

81. Mikhialov, L.; Tsvetinov, P. Evaluation of Services Using a Fuzzy Analytic Hierarchy Process. Appl. Soft. Comput. 2004, 5, 23-33. [CrossRef]

82. Jiang, H.; Eastman, J.R. Application of Fuzzy Measures in Multi-Criteria Evaluation in GIS. Int. J. Geogr. Inf. Sci. 2000, 14, 173-184. [CrossRef]

83. Chen, Y.; Yu, J.; Shahbaz, K.; Xevi, E. A GIS-Based Sensitivity Analysis of Multi-Criteria Weights. In Proceedings of the 18th World IMACS/MODSIM Congress, Cairns, Australia, 13-17 July 2009; pp. 13-17.

84. SaltellI, A.; Tarantola, S.; Campolongo, F.; Ratto, M. Sensitivity Analysis in Practice: A Guide to Assessing Scientific Models, 1st ed.; John Wiley \& Sons: West Sussex, UK, 2004.

85. Xu, E.; Zhang, H. Spatially-Explicit Sensitivity Analysis for Land Suitability Evaluation. Appl. Geogr. 2013, 45, 1-9. [CrossRef]

86. Köeppen, W. Climatologia: Con un Estudio de los Climas de la Tierra; Fondo de Cultura: Mexico City, Mexico, $1948 ;$ p. 474.

87. Chambers, J.C. Seed Movements and Seedling Fates in Disturbed Sagebrush Steppe Ecosystems: Implications for Restoration. Col. Appl. 2000, 10, 1400-1413. [CrossRef]

88. Rey, F.; Isselin-Nondedeu, F.; Bédécarrats, A. Vegetation Dynamics on Sediment Deposits Upstream of Bioengineering Works in Mountainous Marly Gullies in a Mediterranean Climate. Plant Soil. 2005, 278, 149-158. [CrossRef]

89. Spurr, S.H.; Barnes, B.V. Forest Ecology, 2nd ed.; Ronald Press: New York, NY, USA, 1973; p. 575.

90. Leão, S.R.F. Potencial Agrícola dos Solos do Distrito Federal. In Caracterização, Ocupação e Perspectivas; Pinto, M.N., Ed.; UnB: Brasília, Brazil, 1994; pp. 455-468.

91. Jacomine, P.K.T. Solos Sob Matas Ciliares. In Matas Ciliares: Conservação e Recuperação, 2nd ed.; Universidade de São Paulo: São Paulo, Brazil, 2004; pp. 27-31.

92. Correia, J.R.; Reatto, A.; Spera, S.T. Solos e Suas Relações com o Uso e o Manejo. Capítulo 1. In Cerrado Correção do Solo e Adubação; EMBRAPA Cerrados: Brasília, Brazil, 2004; pp. 29-62. Available online: http://www.bdpa.cnptia. embrapa.br / consulta / busca?b=ad\&id=566223\&biblioteca=CPAC\&busca=autoria:\%22REATTO,\%20A. \%22\&qFacets=autoria: \%22REATTO,\%20A.\%22\&sort=\&paginacao=t\&paginaAtual=1 (accessed on 6 May 2020). 
93. Blaser, J.; Sabogal, C. Management Strategies for Degraded Landscapes. In Draft Guidelines for the Restoration of Degraded Primary Forests, the Management of Secondary Forests and the Rehabilitation of Degraded Forest Land in Tropical Regions; Draft report prepared on behalf of ITTO as basis for deliberations of the Expert Panel; ITTO: Bern, Switzerland, 2002.

94. Vieira, I.; Proctor, J. Mechanisms of Plant Regeneration during Succession after Shifting Cultivation in Eastern Amazonia. Vegetable 2007, 192, 303-315. [CrossRef]

95. Eriksson, O.; Ehrle'n, J. Seed and Microsite Limitation of Recruitment in Plant Population. Oecologia 1992, 91, 360-364. [CrossRef] [PubMed]

96. Cerda, A.; Garcia-Fayos, P. The Influence of Seed Size and Shape on Their Removal by Water Erosion. Catena 2002, 48, $293-301$. [CrossRef]

97. Lachlan, S.C.; Dwyer, J.M.; Smith, T.J.; Connors, S.; Marschner, P.; Mayfield, M.M. Species wood density and the location of planted seedlings drive early-stage seedling survival during tropical forest restoration. J. Appl. Ecol. 2018, 55, 1009-1018. [CrossRef]

98. Cheesman, A.W.; Preece, N.; Van Oosterzee, P.; Erskine, P.D.; Cernusak, L.A. The Role of Topography and Plant Functional Traits in Determining Tropical Reforestation Success. J. Appl. Ecol. 2018, 55, 1029-1039. [CrossRef]

99. Hamilton, M.B. Tropical Tree Gene Flow and Seed Dispersal: Deforestation affects the Genetic Structure of the Surviving Forest Fragments. Nature 1999, 401, 129-130. [CrossRef]

100. Tabarelli, M.; Peres, C.A. Abiotic and Vertebrate Seed Dispersal in the Brazilian Atlantic Forest: Implications for Forest Regenerations. Biol. Conserv. 2002, 106, 165-176. [CrossRef]

101. Turner, I.M.; Corlett, R.T. The Conservation Value of Small, Isolated Fragments of Lowland Tropical Rain Forest. Trends. Ecol. Evol. 1996, 11, 330-333. [CrossRef]

102. Pither, R.; Kellman, M. Tree Species Diversity in Small, Tropical Riparian Forest Fragments in Belize, Central America. Biodivers. Conserv. 2002, 11, 1623-1636. [CrossRef]

103. Machado, F.S.; Fontes, M.A.L.; dos Santos, R.M.; Garcia, P.O.; Farrapo, C.L. Tree Diversity of Small Forest Fragments in Ecotonal Regions: Why Must These Fragments Be Preserved? Biodivers. Conserv. 2016, 25, 525-537. [CrossRef]

104. Fahrig, L. Effects of Habitat Fragmentation on Biodiversity. Annu. Rev. Ecol. Evol. Syst. 2003, 34, 487-515. [CrossRef]

105. Gómez-Aparicio, L.; Patrick, H.M.; Charles, D.C. Neighbourhood Models of the Ffects of the Invasive Acer Platanoides on Tree Seedling Dynamics: Linking Impacts on Communities and Ecosystems. J. Ecol. 2008, 96, 78-90. [CrossRef]

106. Ragusa-Netto, J.; Santos, A.A. Seed Rain Generated by Bats under Cerrado's Pasture Remnant Trees in a Neotropical Savanna. Braz. J. Biol. 2015, 75, 25-34. [CrossRef]

107. Hobbs, R.J.; Norton, D.A. Towards a Conceptual Framework for Restoration Ecology. Restor. Ecol. 1996, 4, 93-110. [CrossRef]

108. Parrotta, J.A.; John, W.; Turnbull, N.J. Catalyzing Native Forest Regeneration on Degraded Tropical Lands. For. Ecol. Manag. 1997, 99, 1-7. [CrossRef]

109. Holl, K.D.; Michael, E.L.; Eleanor, H.V.L.; Ivan, A.S. Tropical Montane Forest Restoration in Costa Rica: Overcoming Barriers to Dispersal and Establishment. Restotaition Ecol. 2000, 8, 339-349. [CrossRef]

110. Sansevero, J.B.B.; Prieto, P.; de Moraes, V.; Rodrigues, L.F.D. Natural Regeneration in Plantations of Native Trees in Lowland Brazilian Atlantic Forest: Community Structure, Diversity, and Dispersal Syndromes. Restor. Ecol. 2011, 19, 379-389. [CrossRef]

111. Johst, K.; Brandl, R.; Eber, S. Metapopulation Persistence in Dynamic Landscapes: The Role of Dispersal Distance. Oikos 2002, 98, 263-270. [CrossRef]

112. Howe, H.F.; Miriti, M.N. When Seed Dispersal Matters. Bio. Sci. 2004, 54, 651-660. [CrossRef]

113. Higgins, S.I.; Lavorel, S.; Revilla, E. Estimating Plant Migration Rates under Habitat Loss and Fragmentation. Oikos 2003, 101, 354-366. [CrossRef]

114. Pearson, R.G.; Dawson, T.P. Long-Distance Plant Dispersal and Habitat Fragmentation: Identifying Conservation Targets for Spatial Land-Scape Planning under Climate Change. Biol. Conserv. 2005, 123, 389-401. [CrossRef]

115. Juvanhol, R.S. Análise Espacial De Fragmentos Florestais No Corredor Ecológico Entre Os Parques Estaduais De Forno Grande e Pedra Azul, ES; Universidade Federal do Espirito Santo-UFES: Espirito Santo, Brazil, 2011. [CrossRef]

116. Cavalcante, D.G.; Pinheiro, E.S.; de Macedo, M.A.; Martinot, J.F.; Nascimento, A.A.Z.; Marques, J.P.C. Análise da Vulnerabilidade Ambiental de um Fragmento Florestal Urbano na Amazônia: Parque Estadual Sumaúma. Soc. Nat. 2010, 22, 391-403. [CrossRef]

117. Saunders, D.A.; Hobbs, R.J.; Margules, C.R. Biological Consequence of Ecosystem Fragmentation: A Review. Conserv. Biol. 1991, 5, 18-32. [CrossRef]

118. Tabanez, A.A.J.; Viana, V.M. Patch Structure within Brazilian Atlantic Forest Fragments and Implications for Conservation. Biotropica 2000, 32, 925-933. [CrossRef]

119. Ribeiro, J.F. (Ed.) Cerrado: Matas de Galeria; Embrapa: Planaltina, Brazil, 1998; pp. 1-16.

120. Portela, R.C.Q.; Santos, F.A.M. Litter Production and Accumulation in the Edge and Interior of Atlantic Rain Forest Fragments of Different Sizes. Rev. Bras. Bot. 2007, 30, 271-280. [CrossRef]

121. Lima, A.R.; Capobianco, J.P.R. Mata Atlântica: Avanços Legais e Institucionais para Sua Conservação; Documentos ISA, Instituto Socioambiental: São Paulo, Brazil, 1997.

122. Gomes, E.P.C.; Simey, T.V.F.; Waldir, M. Estrutura e Composição do Componente Arbóreo na Reserva Ecológica do Trabiju, Pindamonhangaba, SP, Brazil. Acta Bot. Bras. 2005, 19, 451-464. [CrossRef]

123. Liddle, M. Recreation Ecology: The Ecological Impact of Outdoor Recreation and Ecotourism; Chapman \& Hall: London, UK, 1997. 
124. Whittington, J.; Clair, C.C.S.; Mercer, G. Spatial Responses of Wolves to Roads and Trails in Mountain Valleys. Ecol. Appl. 2005, 15, 543-553. [CrossRef]

125. Brasil. Lei $n^{\circ}$ 12.651, de 25 de maio de 2012. Dispõe Sobre a Proteção da Vegetação Nativa e dá Outras Providências. Presidência da República. Casa Civil. 2012. Available online: http:/ /www.planalto.gov.br/ccivil_03/_ato2011-2014/2012/lei/112651.htm (accessed on 14 June 2020).

126. Cole, R.J.; Holl, K.D.; Keene, C.L.; Zahawi, R.A. Direct Seeding of Late-Successional Trees to Restore Tropical Montane Forest. For. Ecol. Manag. 2011, 261, 1590-1597. [CrossRef]

127. La Peña-Domene, M.; Martínez-Garza, C.; Ayestarán-Hernández, L.M.; Howe, H.F. Plant Attributes that Drive Dispersal and Establishment Limitation in Tropical Agricultural Landscapes. Forests 2018, 9, 620. [CrossRef]

128. Dos Santos, M.J.C.; Nascimento, A.V.S.; Silva, C.E. Caracterização Dos Remanescentes Florestais Naturais da Zona Rural de Guapiara. Nat. Resour. 2011, 1, 23-36. [CrossRef]

129. Brasil, Empresa Brasileira de Pesquisa Agropecuária. Mapa de Solo/Minas Gerais. 1970. Available online: https: / / www.embrapa. br/mapa-da-embrapa-no-brasil (accessed on 5 July 2019).

130. Eastman, J.R. IDRISI Kilimanjaro: Guide to GIS and Image Processing; Clarke Labs, Clarke University: Worcester, MA, USA, 2003; p. 300.

131. Saaty, T.L. Theory and Applications of the Analytic Network Process: Decision Making with Benefits, Opportunities, Costs, and Risks; RWS Publications: Pittsburgh, PA, USA, 2005; p. 352.

132. Kwiesielewicz, M. A Note on the Fuzzy Extension of Saaty's Priority Theory. Fuzzy Sets Syst. 1998, 95, 161-172. [CrossRef]

133. Chang, D.-Y. Applications of the Extent Analysis Method on Fuzzy AHP. Eur. J. Oper. Res. 1996, 95, 649-655. [CrossRef]

134. Van Laarhoven, P.J.M.; Pedrycz, W. A Fuzzy Extension of Saaty's Priority Theory. Fuzzy Sets Syst. 1983, 11, 229-241. [CrossRef]

135. Gogus, O.; Boucher, T.O. Strong Transitivity, Rationality and Weak Monotonicity in Fuzzy Pairwise Comparisons. Fuzzy Sets Syst. 1998, 94, 133-144. [CrossRef]

136. Vivas Neto, D.C. Corredores Dendríticos em Paisagem Alterada: Uma Proposta Metodológica. 2006. Available online: http: / / www.dominiopublico.gov.br/pesquisa/DetalheObraForm.do?select_action=\&co_obra=61960 (accessed on 9 January 2020). 